Article

\title{
Synthesis of Jacaranone-Derived Nitrogenous Cyclohexadienones and Their Antiproliferative and Antiprotozoal Activities
}

\author{
Armin Presser ${ }^{1, *(D)}$, Gunda Lainer ${ }^{1}$, Nadine Kretschmer ${ }^{2}$, Wolfgang Schuehly ${ }^{2}$, Robert Saf ${ }^{3}$, \\ Marcel Kaiser ${ }^{4,5}$ and Marc-Manuel Kalt ${ }^{1}$ \\ 1 Institute of Pharmaceutical Sciences, Pharmaceutical Chemistry, University of Graz, Schubertstrasse 1, \\ 8010 Graz, Austria; gunda.lainer@edu.uni-graz.at (G.L.); marc.kalt@edu.uni-graz (M.-M.K.) \\ 2 Institute of Pharmaceutical Sciences, Pharmacognosy, University of Graz, Universitaetsplatz 4, \\ 8010 Graz, Austria; nadine.kretschmer@uni-graz.at (N.K.); wolfgang.schuehly@uni-graz.at (W.S.) \\ 3 Institute for Chemistry and Technology of Materials (ICTM), Graz University of Technology, \\ Stremayrgasse 9, 8010 Graz, Austria; robert.saf@tugraz.at \\ 4 Swiss Tropical and Public Health Institute, Socinstrasse 57, 4002 Basel, Switzerland; \\ marcel.kaiser@swisstph.ch \\ 5 University of Basel, Petersplatz 1, 4003 Basel, Switzerland \\ * Correspondence: armin.presser@uni-graz.at; Tel.: +43-316-380-5369
}

Academic Editors: Claudio Santi and Luca Sancineto Received: 26 September 2018; Accepted: 29 October 2018; Published: 7 November 2018

\begin{abstract}
The cytotoxic and antiprotozoal activities of the phytoquinoide, jacaranone, and related compounds have been an ongoing topic in recent drug discovery. Starting from the natural product-derived cyclohexadienone scaffold, a series of nitrogen-containing derivatives were synthesized and subsequently evaluated for their antiproliferative and antiprotozoal activity. Anticancer potency was analyzed using different types of cancer cell lines: MDA-MB-231 breast cancer, CCRF-CEM leukemia, HCT-116 colon cancer, U251 glioblastoma, and, in addition, non-tumorigenic MRC-5 lung fibroblasts. Antiproliferative activities at micromolar concentrations could be shown. Antiprotozoal activity was assessed against Plasmodium falciparum NF54 and Trypanosoma brucei rhodesiense STIB900. For all compounds, selectivity indices (SI) were calculated based on assessed cytotoxicity towards L6 cells. In addition, the structure-activity-relationships and physicochemical parameters of these compounds are discussed.
\end{abstract}

Keywords: antiproliferative activity; antiprotozoal activity; green chemistry; natural products; jacaranone

\section{Introduction}

Natural products (NPs) play vital roles in drug discovery. More than half of the drugs that have been approved over the past 30 years are natural compounds or compounds based on these [1]. Approximately $68 \%$ of anti-infectives are classified as nature-derived or inspired, and $80 \%$ of all anticancer compounds fall into this category [2]. Examples of well-known drugs derived from natural products are paclitaxel or doxorubicin (anticancer), artemisinin (antimalarial), daptomycin (antibacterial), and morphine (analgesic). The most striking feature of many natural products is their structural diversity, which is still largely untapped. About $40 \%$ of the chemical scaffolds found in NPs are still absent in today's medicinal chemistry [3]. The importance of NPs in drug development has been described in a number of reviews and reports [2,4-10].

Jacaranone (1) and its derivatives, phytoquinoids isolated from several Jacaranda and Senecio species, exhibited promising pharmacophore qualities in previous investigations. The remarkable 
cytotoxic and antiprotozoal properties of jacaranone have been especially well-studied both in vitro and in vivo [11-14]. Related nitrogenous NPs (e.g., verongiaquinol (2) or melodamide A (3)) are also valuable drug candidates that possess antiproliferative, antibiotic, antiviral, antiprotozoal, and anti-inflammatory activities [15-20].

Herein, we report the design and synthesis of jacaranone-inspired $N$-containing cyclohexadienones and our findings on the antiproliferative, antiplasmodial, and antitrypanosomal activities of these NP-derived quinols (Figure 1).<smiles>COC(=O)CC1(O)C=CC(=O)C=C1</smiles>

1<smiles>NC(=O)CC1(O)C=C(Br)C(=O)C(Br)=C1</smiles>

2

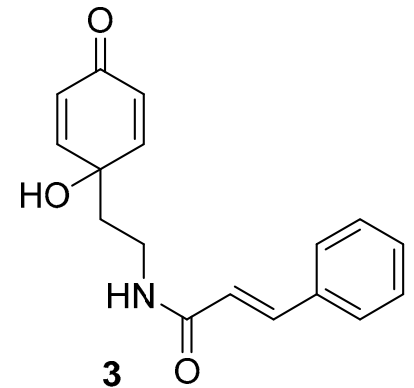

3

Figure 1. Naturally occurring quinols with remarkable biological activity.

\section{Results and Discussion}

\subsection{Chemistry}

Imide derivatives are a valuable group of bioactive compounds. In spite of their wide applicability, available procedures for their synthesis are limited [21]. During the course of our work on jacaranone imides, we searched for an efficient method that we could use to construct the $N$-dienone scaffold.

During our initial attempts, we followed a Mitsunobu route [22] as summarized in Scheme 1 (method A). Starting from the commercially available compound, methyl 4-hydroxyphenyl acetate (4), the temporarily protected alcohol 5 was obtained in two steps in almost quantitative yields. The introduced thexyldimethylsilyl (TDS) group is superior in comparison with other commonly used silyl protecting strategies because of its greater stability and ease of handling [23].

Subsequently, the intermediates $\mathbf{6 a}-\mathbf{c}$ were prepared from TDS ether $\mathbf{5}$ under Mitsunobu conditions and then treated with an excess amount of tetrabutylammonium fluoride (TBAF) [24] to afford the unprotected imides $7 \mathbf{a}-\mathbf{c}$ in moderate overall yields (58-71\%).

Walker [25] reported that yields of the crucial Mitsunobu reaction could be increased by simply altering the order in which the reagents were combined. Although we observed these instructions, following the Mitsunobu route still did not allow us to produce a wide range of imide derivatives.

Therefore, we focused on tyramine (8) as a commercially available and more suitable starting material for our imide design. A previously described method [26] used 8 for the chemoselective condensation with phthalic anhydride in refluxing acetic acid. Following this published protocol as shown in Scheme 1, a series of cyclic imides $(7 \mathbf{a}-\mathbf{j})$ were synthesized in generally good to excellent yields (method B). Furthermore, tyramine has an advantage in that it is significantly more reactive than the formerly used alcohol 5, and the tedious process of protecting the phenolic group is not necessary. Interestingly, the preparation of $\mathbf{7 f}$ and $\mathbf{7 g}$ failed using this procedure, perhaps due to its basicity (7f) or hydrolytic degradation $(\mathbf{7 g})$.

Recently, we have become interested in the development of synthetic methods using polyethylene glycol (PEG) as a novel, environmentally and industrially friendly medium and promoter [27]. It is known that PEG can act as an excellent reaction medium for the synthesis of $N$-alkyl and $N$-arylphthalimides [28]. For this reason, we investigated whether the substitution of the established solvent acetic acid (method B) by the nontoxic, inexpensive, nonionic liquid PEG 400 (method C) was a viable alternative procedure for the condensation of various anhydrides with $\mathbf{8}$. 
<smiles>COC(=O)Cc1ccc(O)cc1</smiles><smiles>[O-][Se+]([O-])(O[Na])c1ccc(CCO)cc1</smiles><smiles></smiles><smiles>NCCc1ccc(O)cc1</smiles>

8
5

6a-c

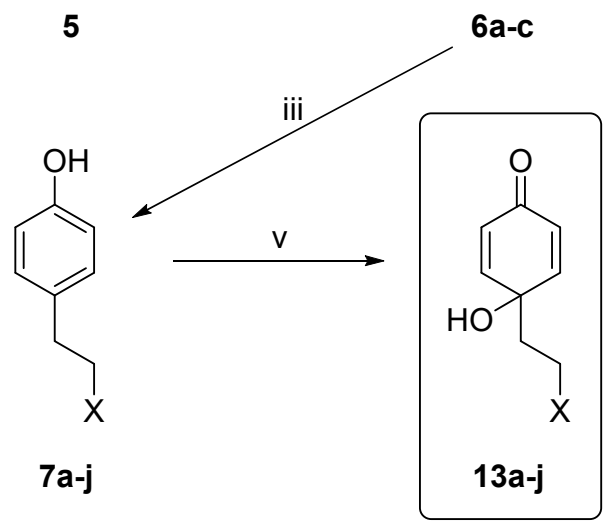<smiles>[R]C#CN1C(=O)C=CC1=O</smiles><smiles>[X]#CN1C(=O)CCC1=O</smiles><smiles></smiles><smiles>[X]C#CN1C(=O)COCC1=O</smiles><smiles>[X]CN1C(=O)C2CCCCC2C1=O</smiles><smiles>[X]#CN1C(=O)C2=C(CCCC2)C1=O</smiles><smiles></smiles>

Scheme 1. Reagents and conditions: method A: (i) 1. TDSCl, DBU, RT, $1.5 \mathrm{~h}$; $2 . \mathrm{LiAlH}_{4}, \mathrm{THF}, 0{ }^{\circ} \mathrm{C}$, 2 h (98\%); (ii) imide, $\mathrm{PPh}_{3}$, DIAD, THF, $0{ }^{\circ} \mathrm{C} \rightarrow \mathrm{RT}, 2.5-24 \mathrm{~h}$ (6a: 90\%, 6b: 70\%, 6c: 77\%); (iii) TBAF, $\mathrm{CH}_{2} \mathrm{Cl}_{2}$, RT, $1 \mathrm{~h}$ (7a: $\left.80 \%, 7 \mathrm{~b}: 85 \%, 7 \mathrm{c}: 82 \%\right)$; (iv) anhydride, $\mathrm{AcOH}, 120{ }^{\circ} \mathrm{C}, 1.5 \mathrm{~h}(\operatorname{method} \mathrm{B}: 7 \mathrm{a}: 73 \%$, 7b: 55\%, 7c: 58\%, 7d: 89\%, 7e: 90\%, 7f: 0\%, 7g: 0\%, 7h: 86\%, 7i: 92\%, 7j: 79\%) or PEG 400, $140{ }^{\circ} \mathrm{C}, 4 \mathrm{~h}$ (method C: 7a: 23\%, 7b: 51\%, 7c: 98\%, 7d: 67\%, 7e: 67\%, 7f: 86\%, 7g: 71\%, 7h: 79\%, 7i: 98\%, 7j: 98\%); (v) $\mathrm{PhI}(\mathrm{OAc})_{2}, \mathrm{CH}_{3} \mathrm{CN} / \mathrm{H}_{2} \mathrm{O}(12: 5), 0{ }^{\circ} \mathrm{C}, 7 \mathrm{~min}(13 \mathrm{a}: 67 \%, 13 \mathrm{~b}: 17 \%, 13 \mathrm{c}: 55 \%, 13 \mathrm{~d}: 40 \%, 13 \mathrm{e}: 64 \%$, 13f: 19\%, 13g: 18\%, 13h: 79\%, 13i: 88\%, 13j: 49\%.

Initially, the modified procedure provided only poor yields because PEG acted as a solubilizer. This led to difficulties during the workup of the highly water-soluble imides. By referring to a PEG-assisted solvent and catalyst-free synthesis of 3,4-dihydropyrimidinones [29], we significantly 
decreased the amount of PEG used in our synthesis. In fact, the results obtained by modifying the method demonstrated that we could considerably increase the product yield in most cases, including the cases of the elusive imides, $7 \mathrm{f}$ and $7 \mathrm{~g}$.

Overall, upon comparing the yields achieved with methods A and B/C, respectively, we could clearly demonstrate the great advantage of using tyramine (8) as a starting material to prepare the cyclic imides, $\mathbf{7 a -} \mathbf{j}$, as well as the potential of using PEG as an excellent reagent to promote organic reactions.

Next, we turned our attention to the preparation of the jacaranone-derived amines. $N$-alkyl amines can be obtained by the catalytic amination of alcohols [30] or by the reaction of the respective amine with alkyl halides and an auxiliary base [31]. Heterocyclic $N$-imides have also been smoothly converted into the corresponding amines with $\mathrm{LiAlH}_{4}$ in excellent yields [32,33]. This route was initially adopted for the synthesis of amines 11a-d from the previous synthesized imides (Scheme 2, method D).
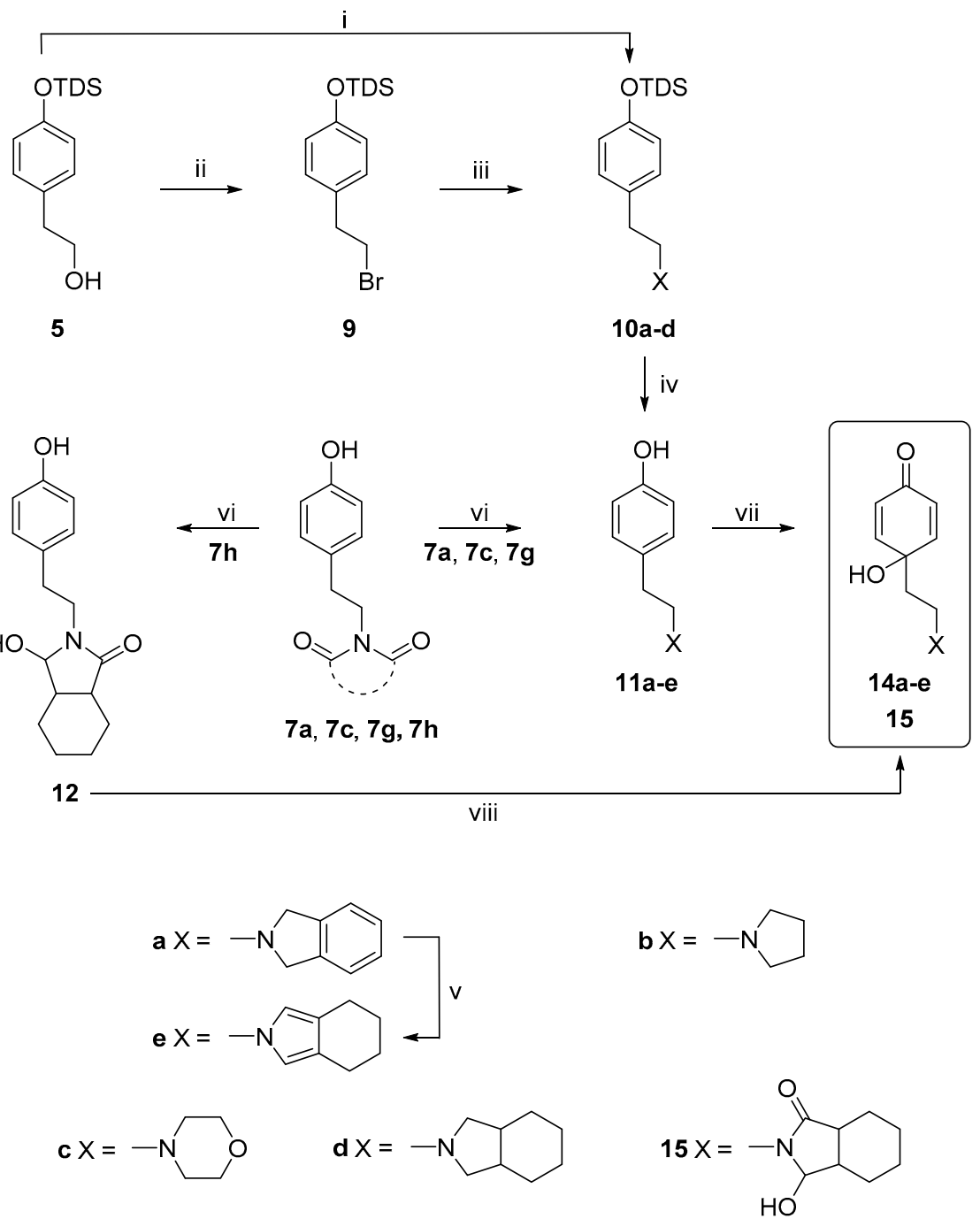

Scheme 2. Reagents and conditions: (i) Pyrrolidine, $\left[\mathrm{Cp}^{*} \mathrm{IrCl}_{2}\right]_{2}(5 \mathrm{~mol} \% \mathrm{Ir}), \mathrm{NaHCO}_{3}$, toluene, $110{ }^{\circ} \mathrm{C}$, 25 h (method E: 10b: 45\%); (ii) $\mathrm{PPh}_{3}, \mathrm{DDQ}, \mathrm{TBAB}, \mathrm{CH}_{2} \mathrm{Cl}_{2}, \mathrm{RT}, 50 \mathrm{~min}(81 \%)$; (iii) secondary amine, NaI, proton sponge ${ }^{\circledR}, \mathrm{CH}_{3} \mathrm{CN}, 20 \mathrm{~h}$ (method F: 10a: 72\%, 10b: 87\%, 10c: 87\%, 10d: 94\%); (iv) LiOH, DMF, RT, 3-17 h (11a: 84\%, 11b: 93\%, 11c: 100\%, 11d: 82\%); (v) ammonium formate, $\mathrm{Pd}(\mathrm{OH})_{2} / \mathrm{C}, \mathrm{MeOH}$, reflux, $16 \mathrm{~h}(100 \%)$; (vi) $\mathrm{LiAlH}_{4}, \mathrm{THF}, 0{ }^{\circ} \mathrm{C}, 90 \mathrm{~min}(\operatorname{method} \mathrm{D}: \mathbf{1 1 a}: 72 \%, \mathbf{1 1 b}: 0 \%, 11 \mathrm{c}: 0 \%, 11 \mathrm{~d}: 0 \%, \mathbf{1 2}$ : $88 \%$ ); (vii) $\mathrm{PhI}(\mathrm{OAc})_{2}, \mathrm{CH}_{3} \mathrm{CN} / \mathrm{H}_{2} \mathrm{O} /$ phosphate buffer (12:3:2), $\mathrm{pH}=6.4,0{ }^{\circ} \mathrm{C}, 7 \mathrm{~min}(\mathbf{1 4 a}: 16 \%, \mathbf{1 4 b}$ : 0\%, 14c: 28\%, 14d: $0 \%$, 14e: $0 \%$ ); (viii) $\mathrm{PhI}(\mathrm{OAc})_{2}, \mathrm{CH}_{3} \mathrm{CN} / \mathrm{H}_{2} \mathrm{O}(12: 5), 0{ }^{\circ} \mathrm{C}, 7 \mathrm{~min}(15: 65 \%)$. 
Watson et al. [32] showed that the reduction of the phthalimide functionality might be problematic due to the comparatively facile oxidation of the emerging isoindoline to the respective isoindole. Surprisingly, the conversion of phthalimide 7a with $\mathrm{LiAlH}_{4}$ gave essentially the isoindoline, 11a, in good yields, whereas the reduction to the amines, $\mathbf{1 1 b}-\mathbf{d}$, failed. In contrast, the partially reduced derivative, 12, was exclusively obtained when $7 \mathrm{~h}$ was treated with $\mathrm{LiAlH}_{4}$.

As an alternative route to the desired jacaranone-derived amines, we examined the frequently used iridium-catalyzed alkylation of alcohols [34] (method E). However, treatment of the primary alcohol, 5, with pyrrolidine in the presence of $\left[\mathrm{Cp}^{*} \mathrm{IrCl}_{2}\right]_{2}$ [35] delivered $\mathbf{1 0 b}$ in only moderate yields; thus, this synthetic route was abandoned.

Finally, we applied the traditional amination of alkyl halogenides for the preparation of jacaranone amines (method F). For this purpose, alcohol 5 was first converted with tetrabutyl ammonium bromide (TBAB), $\mathrm{PPh}_{3}$, and 2,3-dichloro-5,6-dicyanobenzoquinone (DDQ) [36] to the corresponding bromide 9. This intermediate was then coupled with the appropriate secondary amine in the presence of $\mathrm{NaI}$ and proton sponge ${ }^{\circledR}$ [37] to obtain the amines, $\mathbf{1 0 b}-\mathbf{d}$, in good to excellent yields. Only the $N$-alkylation of isoindoline (10a) led to slightly lower yields under these conditions. Deprotection of the obtained amines, 10a-d, with LiOH in DMF [38] was successful, resulting in the desired derivatives, 11a-d.

Previous studies have demonstrated that isoindolines can be readily converted to tetrahydroisoindoles by palladium hydroxide-catalyzed hydrogenation $[39,40]$. To broaden the range of usable amines, we examined the reported procedure and observed a quantitative conversion of 11a to the expected tetrahydroisoindole, 11e.

Finally, we investigated the oxidative dearomatization of the synthesized $N$-containing phenols into the respective p-alkyl quinols. Such cyclic dienones exhibit not only promising pharmacophores [3,41], but are also attractive intermediates for enantioselective natural product synthesis [42-44]. Phenol dearomatization processes are generally mediated by hypervalent iodine reagents, and are well-documented in the literature $[43,45]$. The commonly used protocol using phenyliodine(III) diacetate (PIDA) in aqueous $\mathrm{CH}_{3} \mathrm{CN}$ [46] appeared to be most suitable for our purpose.

The conversion of the compounds, $\mathbf{7 a}-\mathbf{j}$ and 12, with PIDA afforded the respective p-substituted cyclohexadienones, $\mathbf{1 3} \mathbf{a}-\mathbf{j}$ and $\mathbf{1 5}$, in satisfactory yields, whereas the oxidation of all tertiary amines (11a-e) failed. To improve the rate of conversion for these compounds, we examined the impact of varying the $\mathrm{pH}$ values on the reaction outcome. The best results were obtained applying a $1 \mathrm{M}$ phosphate buffer that adjusted the $\mathrm{pH}$ to 6.4 during the oxidation. This variation led to the availability of a few additional tertiary jacaranone amines $(\mathbf{1 4 a}, \mathbf{1 4 c})$, but the yields still remained far from being satisfactory.

Subsequently, the synthesized dienones were evaluated for their antiproliferative and antiprotozoal activity, following the method described in the Experimental section.

\subsection{Physicochemical Properties}

Physicochemical parameters play crucial roles in the selection process of drug candidates for product development. The properties of small molecules, especially those that are orally bioavailable, are concentrated in a relatively narrow range of physicochemical space known as the "drug-like space" [47]. An optimal lipophilicity range, along with low molecular weight and small polar surface area, are major prerequisites that lead to good absorption of chemicals by the intestine through passive diffusion [48,49]. For this reason, an assessment of drug-likeness was made, and various physicochemical properties were calculated for all tested compounds (Table 1 and Supplementary Materials). 
All compounds had relatively low molecular weights within the range of $223-352 \mathrm{~g} \cdot \mathrm{mol}^{-1}$. Their polar surface areas are low and well within the range where good central nervous system (CNS) penetration is plausible [50,51]. The latter parameter is especially important to treat the CNS-persistent second stage of human African trypanosomiasis (HAT) [52]. All derivatives fulfill the Lipinski rule of five [53] and the Veber rule [54]. Except for imides, 13c and 13g, the logP data of which lie slightly outside the proposed region, all mentioned compounds also comply with the drug-likeness classifier defined by Ghose et al. [55].

The adequate application of ligand efficiency (LE) metrics is of utmost relevance in guiding lead discovery - and, more importantly, lead optimization-towards drug-like chemical space [56,57]. The ligand efficiency metrics of our synthesized compounds (LE $>\sim 0.3$ ), lipophilic ligand efficiency (LLE) (LLE > 5), and lipophilicity-corrected ligand efficiency (LELP) $(-10<$ LELP < 10) agree closely with the values proposed for drug candidates [56] (see Supplementary Materials, Table S3).

In addition, all synthesized dienones were subjected to the BOILED-Egg analysis [58,59], an improvement upon the well-known Egan egg model [60]. This tool utilizes the computed lipophilicity and polarity of small drugs as input, allowing researchers to predict brain and intestinal permeation efficacies. This model is frequently used in industrial and academic contexts for drug discovery and development. All computed substances are within the thresholds of the model and, therefore, are predicted to show good gastrointestinal absorption. Furthermore, compounds, 13d and 14a, also lie within the physicochemical space of molecules that have a high probability of permeating the blood-brain barrier (BBB) (see Supplementary Materials, Figure S1).

\subsection{Biological Evaluation}

\subsubsection{Antiproliferative Activity}

All synthesized dienones (13a-j, 14a, 14c, and 15) were evaluated for their cytotoxic activity against human (cancer) cell lines. To cover a range of different tumor entities, we used a panel of cancer cell lines (CCRF-CEM leukemia, MDA-MB-231 breast cancer, HCT-116 colon cancer, and U251 glioblastoma cells) as well as a non-tumorigenic human cell line (MRC-5 lung fibroblasts). All derivatives were screened for their cytotoxicity at $5 \mu \mathrm{g} / \mathrm{mL}$ and $50 \mu \mathrm{g} / \mathrm{mL}$ to cover a broad concentration range. Cells were exposed to the derivatives for $72 \mathrm{~h}$. As can be seen in Figure 2, the highest cytotoxicity was found for $\mathbf{1 3 b}$ and $\mathbf{1 3 i}$. Both compounds reduced the metabolic activity below $40 \%$ of the control at $5 \mu \mathrm{g} / \mathrm{mL}$ in all (13i) or almost all (13b) cell lines. At $50 \mu \mathrm{g} / \mathrm{mL}$, almost all tested compounds displayed activities against leukemia and breast cancer cells lines, but the overall cytotoxicity of compounds $\mathbf{1 3 f}, \mathbf{1 3} \mathbf{g}, \mathbf{1 3} \mathbf{j}$, and $\mathbf{1 4 a}$ was negligible. Furthermore, the $50 \mu \mathrm{g} / \mathrm{mL}$ dilution corresponds to concentrations in the 140-215 $\mu \mathrm{M}$ range, which is not considered to be active. Interestingly, the morpholine derivative, 14c, displayed only minor cytotoxicity against most cell lines at $5 \mu \mathrm{g} / \mathrm{mL}$, but subsequently exhibited the highest antitrypanosomal activity. No clear correlation between cytotoxic and antiprotozoal effects could be drawn. Against human MRC-5 cells, 13f, 13g, 13j, and 14a did not show any cytotoxicity at $5 \mu \mathrm{g} / \mathrm{mL}$ and only a weak activity at $50 \mu \mathrm{g} / \mathrm{mL}$. These results essentially match those of the subsequent L6 cytotoxicity assay, which was performed during the antiprotozoal screening. In that series, the highest $\mathrm{IC}_{50}$ values (and, therefore, the lowest cytotoxicity) were found for compounds 13b, 13f, and $\mathbf{1 3} \mathrm{g}$ (for detailed results, see Supplementary Materials, Table S4). 


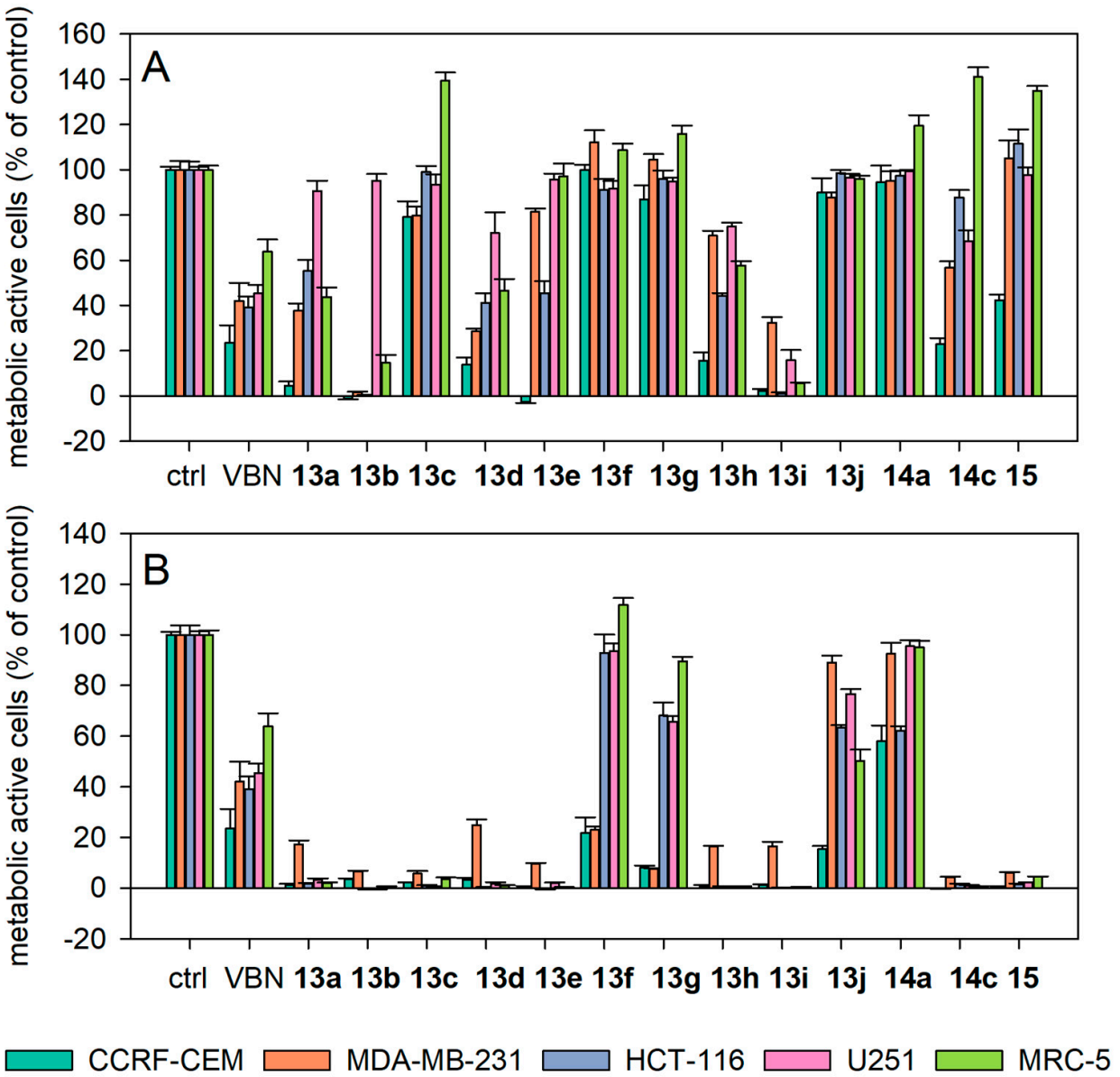

Figure 2. Results of the $\mathrm{XTT}^{\mathrm{a}}$ viability assay using leukemia (CCRF-CEM), breast cancer (MDA-MB-231), colon cancer (HCT-116), and glioblastoma cells (U251) as well as non-tumorigenic lung fibroblasts (MRC-5). Cells were treated with $5 \mu \mathrm{g} / \mathrm{mL}$ (A) or $50 \mu \mathrm{g} / \mathrm{mL}$ (B) of the derivatives for $72 \mathrm{~h}$. Afterwards, the metabolic activities of the cells were measured. Vinblastine (VBN) served as the positive control $(0.01 \mu \mathrm{g} / \mathrm{mL})$. The results are expressed as a percentage of vehicle-treated (0.5\% DMSO) control cells (ctrl) (mean \pm s.e.m., $n=6) .{ }^{\text {a }}$ (2,3-Bis-(2-methoxy-4-nitro-5-sulfophenyl)2H-tetrazolium-5-carboxanilide).

\subsubsection{Antiprotozoal Activity}

The synthesized dienones were also investigated for their activity against $P$. falciparum NF54 and T. brucei rhodesiense STIB900 as well as for their cytotoxicity against L6 rat skeletal myoblasts (Table 1). For each parasite, a selectivity index $\left(\mathrm{SI}=\mathrm{IC}_{50(\mathrm{~L} 6)} / \mathrm{IC}_{50 \text { (parasite) }}\right)$ was calculated. The TDR (Special Program for Research and Training in Tropical Diseases, World Health Organization) criteria [61] were adopted to interpret antiparasitic activity and selectivity.

All derivatives showed moderate $\left(\mathrm{IC}_{50}=1-10 \mu \mathrm{M}\right)$ or high $\left(\mathrm{IC}_{50}<1 \mu \mathrm{M}\right)$ activity towards T. brucei rhodesiense, except the inactive pyridine-2,3-dicarboximide, 13f, and the morpholine-3,5-dione, $13 \mathrm{~g}$, with $\mathrm{IC}_{50}$ values $>10 \mu \mathrm{M}$. These results were surprising, especially in the case of compound 13f, as basic, nitrogen-containing compounds often show favorable activities against protozoal parasites. Interestingly, the corresponding morpholine derivative, 14c, showed, in contrast, the highest antitrypanosomal activity $\left(\mathrm{IC}_{50}=0.27 \mu \mathrm{M}\right)$ of all the tested $N$-dienones. Compared to the antitrypanosomal activity, the antiplasmodial effects of all tested compounds against $P$. falciparum NF54 strains were rather weak. Notable in this series, unfortunately, was the lack of selectivity of most compounds, as the compounds showed selectivity indices (SI) of $<13$. 
Table 1. In vitro antiparasitic activity, host toxicity, and key physicochemical properties of tested compounds.

\begin{tabular}{|c|c|c|c|c|c|c|c|c|}
\hline Compd. & P. falc. ${ }^{\mathrm{a}}$ & $\mathrm{SI}^{b}$ & T.b.rhod. ${ }^{\mathrm{c}}$ & $\mathrm{SI}^{\mathrm{b}}$ & Cyt. L6 ${ }^{d}$ & Chemical Structure & $\log P$ & tPSA (7.4) \\
\hline & $\mathrm{IC}_{50}(\mu \mathrm{M})$ & & $\mathrm{IC}_{50}(\mu \mathrm{M})$ & & $\mathrm{IC}_{50}(\mu \mathrm{M})$ & & & \\
\hline $\begin{array}{l}\text { Chl. } \\
\text { Mel. } \\
\text { Pod }\end{array}$ & 0.002 & & 0.004 & & 0.007 & & & \\
\hline $13 a$ & 3.78 & 1.3 & 1.58 & 3.2 & 5.08 & & 0.85 & 74.68 \\
\hline $13 b$ & 4.42 & 6.1 & 2.15 & 12.5 & 26.80 & & -0.18 & 74.68 \\
\hline $13 c$ & 8.63 & 1.1 & 6.93 & 1.4 & 9.90 & & -0.60 & 74.68 \\
\hline $13 d$ & 3.24 & 1.9 & 5.71 & 1.1 & 6.28 & & 1.89 & 74.68 \\
\hline $13 e$ & 74.38 & 0.1 & 2.26 & 4.5 & 10.26 & & -0.38 & 74.68 \\
\hline
\end{tabular}


Table 1. Cont

\begin{tabular}{|c|c|c|c|c|c|c|c|c|}
\hline Compd. & P. falc. ${ }^{\mathbf{a}}$ & $\mathrm{SI}^{\mathrm{b}}$ & T.b.rhod. ${ }^{\mathrm{c}}$ & $\mathrm{SI}^{\mathrm{b}}$ & Cyt. L6 ${ }^{d}$ & Chemical Structure & $\log P$ & tPSA (7.4) \\
\hline & $\mathrm{IC}_{50}(\mu \mathrm{M})$ & & $\mathrm{IC}_{50}(\mu \mathrm{M})$ & & $\mathrm{IC}_{50}(\mu \mathrm{M})$ & & & \\
\hline $13 f$ & 28.04 & 5.5 & 44.75 & 3.4 & 153.48 & & -0.06 & 87.57 \\
\hline $13 \mathrm{~g}$ & 11.82 & 6.6 & 15.32 & 5.1 & 77.54 & & -1.13 & 83.91 \\
\hline $13 \mathrm{~h}$ & 3.04 & 1.0 & 1.70 & 1.7 & 2.96 & & 0.81 & 74.68 \\
\hline $13 \mathbf{i}$ & 1.28 & 2.7 & 0.80 & 4.4 & 3.52 & & 0.66 & 74.68 \\
\hline $13 \mathbf{j}$ & 3.93 & 2.0 & 0.97 & 8.3 & 8.04 & & 0.55 & 74.68 \\
\hline
\end{tabular}


Table 1. Cont.

\begin{tabular}{|c|c|c|c|c|c|c|c|c|}
\hline Compd. & P. falc. ${ }^{\mathrm{a}}$ & $\mathbf{S I}^{\mathbf{b}}$ & T.b.rhod. ${ }^{\mathrm{c}}$ & $\mathrm{SI}^{\mathbf{b}}$ & Cyt. L6 $^{\mathrm{d}}$ & Chemical Structure & $\log P$ & tPSA (7.4) \\
\hline & $\mathrm{IC}_{50}(\mu \mathrm{M})$ & & $\mathrm{IC}_{50}(\mu \mathrm{M})$ & & $\mathrm{IC}_{50}(\mu \mathrm{M})$ & & & \\
\hline $14 a$ & 2.91 & 1.0 & 0.57 & 4.9 & 2.81 & & 1.89 & 41.74 \\
\hline $14 \mathrm{c}$ & 10.93 & 0.3 & 0.27 & 12.9 & 3.46 & & 0.04 & 49.77 \\
\hline 15 & 6.18 & 2.0 & 1.52 & 8.3 & 12.63 & & 0.58 & 77.84 \\
\hline
\end{tabular}

a P. falciparum, strain NF54, erythrocytic stages; ${ }^{\mathrm{b}} \mathrm{SI}$ is the ratio: $\mathrm{IC}_{50}$ in L6 cells $/ \mathrm{IC}_{50}$ in each parasite; ${ }^{\mathrm{c}}$ T. brucei rhodesiense, strain STIB900 trypomastigote forms; ${ }^{\mathrm{d}}$ cytotoxicity L6 cells rat skeletal myoblasts. Reference drugs: Chloroquine (chl., $\mathrm{IC}_{50}=0.002 \pm 0.001$ ), melarsoprol (mel., $\mathrm{IC}_{50}=0.004 \pm 0.003$ ), podophyllotoxin (pod., $\mathrm{IC}_{50}=0.007 \pm 0.002$ ). The $\mathrm{IC}_{50}$ value of each reference drug is the mean from multiple measurements taken in parallel with the compounds of interest. IC $\mathrm{C}_{50}$ values of the tested compounds are means of two to three independent assays. The individual $\mathrm{IC}_{50}$ values within each assay varied $<25 \%$. The physical properties were predicted by using Marvin 18.10.0, ChemAxon (https:/ /www.chemaxon.com). 


\subsubsection{Structure-Activity Relationships (SAR) of the Antiproliferative and Antiprotozoal Activity}

The mechanism of action of compounds with quinoid structural elements is based on redox cycling with excessive generation of reactive oxygen species (ROS) in the intracellular environment [62]. ROS play central roles in cell signaling and are able to activate the intrinsic pathway of cell apoptosis [63]. It is expected that these processes are responsible for the cytotoxic action of quinoids on microorganisms, as well as on tumor cells [64]. Due to the nature of the presented compounds, target specific effects are few and far between. For instance, the antiproliferative effects of the phytoquinoid, jacaranone, are caused by its interactions with the protein kinase B (AKT) and mitogen-activated protein kinase (p38 MAPK) signaling pathways [13].

Nevertheless, a closer examination of the SARs of jacaranone-based nitrogenous cyclohexadienones with regard to their antiproliferative activity (Figure 2) suggests that the most potent compounds, 13b, 13e, and 13i, share an $\alpha, \beta$-unsaturated imide as a core structural element (Figure 3).

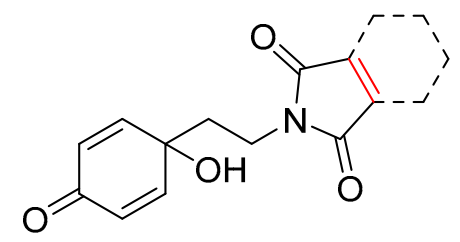

Figure 3. Crucial scaffold for antiproliferative activity.

These compounds showed high activity levels against some (13b: CCRF-CEM, MDA-MB-231, HCT-116; 13e: CCRF-CEM) or all (13i) tested cell lines at low concentrations. Compound 13b also showed a comparably low cytotoxicity against L6 cells with an $\mathrm{IC}_{50}$ of $26.8 \mu \mathrm{M}$, hinting that it has a target-specific inhibitory effect. In contrast, pyridine-2,3-dicarboximide, 13f, and the morpholine-3,5-dione, 13g, exhibited neither cytotoxic nor antiprotozoal activity.

Unfortunately, our antiprotozoal assays revealed no specific effects. However, a certain rank correlation between antiplasmodial activity and $\log P\left(r_{S}=-0.772\right)$ or ASApho values $\left(r_{S}=-0.711\right)$ on one side and antitrypanosomal activity and ASApol $\left(r_{S}=0.870\right)$ on the other side was observed (see also Supplementary Materials, Table S2).

\section{Experimental Section}

\subsection{Chemicals and Instruments}

Melting points were obtained on a digital melting point apparatus (Electrothermal IA 9200, Staffordshire, UK). The NMR spectra were measured on a Unity Inova $400 \mathrm{MHz}$ instrument (Varian, Darmstadt, Germany) and a Avance III 300 MHz NMR Spectrometer (Bruker, Rheinstetten, Germany) at $25{ }^{\circ} \mathrm{C}$ using $5 \mathrm{~mm}$ tubes. Chemical shifts were given in parts per million (ppm), the tetramethylsilane (TMS) resonance $(0.00 \mathrm{ppm})$ was used as an internal standard. Coupling constants $(J)$ were reported in hertz (Hz). ${ }^{1} \mathrm{H}$ and ${ }^{13} \mathrm{C}$-resonances were assigned using ${ }^{1} \mathrm{H},{ }^{1} \mathrm{H}$, and ${ }^{1} \mathrm{H}^{13} \mathrm{C}$ correlation spectra. ${ }^{1} \mathrm{H}$ and ${ }^{13} \mathrm{C}$ resonances are numbered as given in the formulae (see Supplementary Materials).

High-resolution EI mass spectra $\left(70 \mathrm{eV}\right.$, source temperature $\left.220{ }^{\circ} \mathrm{C}\right)$ were recorded on an orthogonal TOF spectrometer (Waters GCT Premier, Milford, MA, USA) equipped with a direct insertion (DI) probe. Typically, $0.2 \mu \mathrm{L}$ of a solution of the sample $(\mathrm{c}=0.1 \mathrm{mg} / \mathrm{mL}$ ) were placed in the glass cup used for DI, dried under atmospheric pressure, and transferred into the vacuum. Mass spectra (50-800 Da; 1 spectrum/s; resolution appr. 7500 FWHM) were continuously acquired while the sample was evaporated rapidly. ESI mass spectra were acquired on an Exactive Orbitrap mass spectrometer equipped with a heated ESI II source (ThermoFisher Scientific, Inc., Bremen, Germany).

HPLC separations were performed on an Agilent HPLC instrument 1200 series (Santa Clara, CA, USA) with quaternary pump, autosampler, autoinjector, column oven, and DAD detection. A Eurospher C18 column (particle size $1.8 \mu \mathrm{m} ; 2.0 \times 125 \mathrm{~mm}$ with guard cartridge) (Knauer, Berlin, 
Germany) was used for analysis of the compounds at a flow rate of $150 \mu \mathrm{L} / \mathrm{min}$ and at a constant temperature of $25{ }^{\circ} \mathrm{C}$. The chromatographic method was performed with a gradient of acetonitrile (A) in millipore water (B), both with each $0.1 \% \mathrm{HCOOH}$, from $10 \%$ to $90 \% \mathrm{~A}$ in $\mathrm{B}$ within 20 min, then to $100 \%$ A within $5 \mathrm{~min}$, followed by returning to starting conditions within $1 \mathrm{~min}$, and re-equilibration for $8 \mathrm{~min} .5 .0 \mu \mathrm{L}$ of sample dissolved in methanol were injected and detection was done at 205, 220, and $254 \mathrm{~nm}$. As assayed through HPLC-DAD analysis, all tested compounds possessed a purity higher than $95 \%$.

Materials: TLC was carried out on TLC plates (silica gel $60 F_{254} 0.2 \mathrm{~mm}, 200 \times 200 \mathrm{~mm}$ ) (Merck, Darmstadt, Germany). TLCs were visualized by spraying with cerium(IV) sulfate/ammonium molybdate and subsequent heating with a heat gun. The phosphate buffer $(1 \mathrm{M}, \mathrm{pH}=6.4)$ was prepared as follows: $7.1 \mathrm{~g}(0.05 \mathrm{mmol}) \mathrm{Na}_{2} \mathrm{HPO}_{4}$ and $6.9 \mathrm{~g}(0.05 \mathrm{mmol}) \mathrm{NaH}_{2} \mathrm{PO}_{4} \times \mathrm{H}_{2} \mathrm{O}$ was dissolved in $\mathrm{H}_{2} \mathrm{O}$ and diluted to $100 \mathrm{~mL}$ with the same solvent. The $\mathrm{pH}$ was controlled using a $\mathrm{pH}$-meter and, if necessary, adjusted to a $\mathrm{pH}$ of 6.4 . Solvents were concentrated by rotary evaporation below $50{ }^{\circ} \mathrm{C}$. Purity and homogeneity of compounds were assessed by the TLC and HPLC methods.

The intermediates, $\mathbf{6 a}-\mathbf{c}$, were prepared via Mitsunobu reaction according to the literature [22], and the subsequent deprotection step was accomplished with TBAF according to the literature [24]. Proton sponge $^{\circledR}$ (1,8-bis(dimethylamino)naphthalene) and other chemicals were purchased from Sigma-Aldrich (Vienna, Austria). All reagents and chemicals were used without any further purification.

\subsection{Synthesis}

2-[4-(Thexyldimethylsilyloxy)phenyl]ethanol (5). To a stirred solution of methyl 4-hydroxyphenylacetate $4(1.2 \mathrm{~g}, 7.2 \mathrm{mmol})$ in anhydrous $\mathrm{CH}_{2} \mathrm{Cl}_{2}(12 \mathrm{~mL}), 1.3 \mathrm{~mL} \mathrm{1,8-diazabicyclo[5.4.0]undec-7-ene} \mathrm{(8.7} \mathrm{mmol)}$ and $1.6 \mathrm{~mL}$ thexyldimethylsilyl chloride $(8.0 \mathrm{mmol})$ were added successively at $0{ }^{\circ} \mathrm{C}$. The mixture was allowed to reach ambient temperature until TLC showed complete consumption of the starting material $(1.5 \mathrm{~h})$. The reaction mixture was diluted with $\mathrm{H}_{2} \mathrm{O}$ and extracted three times with EtOAc. The combined organic layers were dried over $\mathrm{Na}_{2} \mathrm{SO}_{4}$ and evaporated to dryness. The crude product was purified by flash chromatography using cyclohexane $(\mathrm{CH}) / \mathrm{EtOAc}(3: 1)$ to obtain 2-[4-(thexyldimethylsilyloxy)phenyl]-acetate in quantitative yield as a colourless oil.

The residual oil was dissolved in $12 \mathrm{~mL}$ of anhydrous THF and then slowly treated with $7.2 \mathrm{~mL}$ $\mathrm{LiAlH}_{4}\left(1 \mathrm{M}\right.$ solution in THF) at $0{ }^{\circ} \mathrm{C}$. After the addition of $\mathrm{LiAlH}_{4}$ was completed, the reaction was allowed to reach ambient temperature for $2 \mathrm{~h}$. A $2 \mathrm{M}$ aqueous solution of $\mathrm{Na} / \mathrm{K}$ tartrate $(40 \mathrm{~mL}) \mathrm{was}$ slowly added at $0{ }^{\circ} \mathrm{C}$ to quench the reaction and the mixture was stirred for $1 \mathrm{~h}$. Then, the solution was extracted three times with $\mathrm{MTBE}$, the combined organic layers were dried over $\mathrm{Na}_{2} \mathrm{SO}_{4}$, and concentrated in vacuo to yield $2.0 \mathrm{~g}(98 \%)$ of crude 5 as a clear, colourless oil, which was used without further purification. $R_{\mathrm{f}}=0.27(\mathrm{CH}: \mathrm{EtOAc}=2: 1) ;{ }^{1} \mathrm{H}-\mathrm{NMR}\left(400 \mathrm{MHz}, \mathrm{CDCl}_{3}\right) \delta 7.08(\mathrm{~d}, J=8.5 \mathrm{~Hz}, 2 \mathrm{H}$, H-2/6), 6.78 (d, J = 8.5 Hz, 2H, H-3/5), 3.82 (t, J = 6.5 Hz, 2H, H-8), 2.80 (t, J = 6.5 Hz, 2H, H-7), 1.73 (hept, $\left.J=6.9 \mathrm{~Hz}, 1 \mathrm{H}, \mathrm{CH}-\left(\mathrm{CH}_{3}\right)_{2}\right), 0.94\left(\mathrm{~d}, J=6.9 \mathrm{~Hz}, 6 \mathrm{H},\left(\mathrm{CH}_{3}\right)_{2}-\mathrm{CH}\right), 0.94\left(\mathrm{~s}, 6 \mathrm{H},\left(\mathrm{CH}_{3}\right)_{2}-\mathrm{C}\right), 0.21$ (s, 6H, $\left.\left(\mathrm{CH}_{3}\right)_{2}-\mathrm{Si}\right) \mathrm{ppm} ;{ }^{13} \mathrm{C}-\mathrm{NMR}\left(100 \mathrm{MHz}, \mathrm{CDCl}_{3}\right) \delta 154.1$ (C-4), $130.8(\mathrm{C}-1), 129.9(\mathrm{C}-2 / 6), 120.2$ (C-3/5), $63.8(\mathrm{C}-8), 38.4(\mathrm{C}-7), 34.1\left(\mathrm{CH}-\left(\mathrm{CH}_{3}\right)_{2}\right), 25.0\left(\mathrm{C}-\left(\mathrm{CH}_{3}\right)_{2}\right), 20.1\left(\left(\mathrm{CH}_{3}\right)_{2}-\mathrm{C}\right), 18.6\left(\left(\mathrm{CH}_{3}\right)_{2}-\mathrm{CH}\right)$, $-2.5\left(\left(\mathrm{CH}_{3}\right)_{2}-\mathrm{Si}\right)$ ppm; HRMS (ESI) calcd. for $\mathrm{C}_{16} \mathrm{H}_{29} \mathrm{O}_{2} \mathrm{Si}[\mathrm{M}+\mathrm{H}]^{+}=281.1937$; Found: 281.1931 .

\subsubsection{General Procedure for the Synthesis of the Compounds, $\mathbf{7 a - 7 j}$}

AcOH-assisted condensation. A mixture of tyramine $8(274 \mathrm{mg}, 2.0 \mathrm{mmol})$ and the corresponding anhydride $(1.9 \mathrm{mmol})$ in glacial acetic acid $(3 \mathrm{~mL})$ were refluxed for $1.5 \mathrm{~h}$. After cooling of the reaction mixture to ambient temperature, cold $\mathrm{H}_{2} \mathrm{O}(10 \mathrm{~mL})$ was added and the resultant precipitate was filtered, washed several times with cold water, and dried under reduced pressure (7a, 7e). When the product did not precipitate from the solution $(\mathbf{7 b}-\mathbf{d}, \mathbf{7} \mathbf{h}-\mathbf{j}), \mathrm{H}_{2} \mathrm{O}(15 \mathrm{~mL})$ was added, and the aqueous phase was extracted several times with EtOAc. The combined organic layers were washed with $1 \mathrm{M}$ $\mathrm{NaHCO}_{3}$, dried over $\mathrm{Na}_{2} \mathrm{SO}_{4}$, and concentrated in vacuo to yield the crude products, which were used without further purification. 
PEG 400-assisted condensation. A mixture of tyramine $8(274 \mathrm{mg}, 2.0 \mathrm{mmol})$ and the corresponding anhydride $(1.9 \mathrm{mmol})$ in PEG $400(0.3 \mathrm{~mL})$ was heated under stirring at $140{ }^{\circ} \mathrm{C}$ for $4 \mathrm{~h}$. After cooling to ambient temperature, a large quantity of ice-water $(\sim 30 \mathrm{~mL})$ was added. The resultant precipitate was filtered, washed several times with cold water, and dried under reduced pressure $(7 \mathbf{a}, 7 \mathbf{7})$. For $\mathbf{7 b}-\mathbf{d}$ and $\mathbf{7 f}-\mathbf{j}$, the aqueous phase was extracted several times with EtOAc, the combined organic layers were dried over $\mathrm{Na}_{2} \mathrm{SO}_{4}$, and evaporated to dryness. The crude products were purified by flash chromatography (7a-c and $\mathbf{7 e - j}$ ) or recrystallization from EtOAc/acetone/EtOH (30:5:5) (7d).

4-(Thexyldimethylsilyloxy)phenethyl bromide (9). To a stirred solution of $\mathrm{PPh}_{3}(1.3 \mathrm{~g}, 5.0 \mathrm{mmol})$ in anhydrous $\mathrm{CH}_{2} \mathrm{Cl}_{2}(10 \mathrm{~mL})$, DDQ $(1.1 \mathrm{~g}, 5.0 \mathrm{mmol})$ was added slowly at room temperature. Then, (n-butyl) ${ }_{4} \mathrm{NBr}(1.6 \mathrm{~g}, 5.0 \mathrm{mmol})$ and $1.2 \mathrm{~g}(4.2 \mathrm{mmol})$ of alcohol 5 (dissolved in an additional $5 \mathrm{~mL}$ of anhydrous $\mathrm{CH}_{2} \mathrm{Cl}_{2}$ ) were added in 10 min intervals to the thick, beige-coloured mixture. After the addition of 5 , the colour of the reaction mixture immediately changed to deep red. The reaction was stirred for $50 \mathrm{~min}$ at an ambient temperature until TLC showed complete consumption of the starting material. The solvent was evaporated to dryness, and the crude product was purified by flash chromatography using $\mathrm{CH} /$ EtOAc $(1: 1)$ to obtain $1.4 \mathrm{~g}(81 \%)$ of 9 as yellow oil. $R_{\mathrm{f}}=0.70$ (CH:EtOAC $=1: 1) ;{ }^{1} \mathrm{H}-\mathrm{NMR}\left(400 \mathrm{MHz}, \mathrm{CDCl}_{3}\right) \delta 7.05(\mathrm{~d}, J=8.4 \mathrm{~Hz}, 2 \mathrm{H}, \mathrm{H}-2 / 6), 6.77(\mathrm{~d}, J=8.5 \mathrm{~Hz}, 2 \mathrm{H}, \mathrm{H}-3 / 5)$, $3.52(\mathrm{t}, J=7.8 \mathrm{~Hz}, 2 \mathrm{H}, \mathrm{H}-8), 3.08(\mathrm{t}, J=7.8 \mathrm{~Hz}, 2 \mathrm{H}, \mathrm{H}-7), 1.72\left(\mathrm{hept}, J=6.9 \mathrm{~Hz}, 1 \mathrm{H}, \mathrm{CH}-\left(\mathrm{CH}_{3}\right)_{2}\right)$, $0.94\left(\mathrm{~d}, J=6.9 \mathrm{~Hz}, 6 \mathrm{H},\left(\mathrm{CH}_{3}\right)_{2}-\mathrm{CH}\right), 0.94\left(\mathrm{~s}, 6 \mathrm{H},\left(\mathrm{CH}_{3}\right)_{2}-\mathrm{C}\right), 0.21\left(\mathrm{~s}, 6 \mathrm{H},\left(\mathrm{CH}_{3}\right)_{2}-\mathrm{Si}\right) \mathrm{ppm} ;{ }^{13} \mathrm{C}-\mathrm{NMR}$ $\left(100 \mathrm{MHz}, \mathrm{CDCl}_{3}\right) \delta 154.4(\mathrm{C}-4), 131.5(\mathrm{C}-1), 129.6$ (C-2/6), $120.2(\mathrm{C}-3 / 5), 38.8(\mathrm{C}-7), 34.1\left(\mathrm{CH}-\left(\mathrm{CH}_{3}\right)_{2}\right)$, $33.3(\mathrm{C}-8), 25.0\left(\mathrm{C}-\left(\mathrm{CH}_{3}\right)_{2}\right), 20.1\left(\left(\mathrm{CH}_{3}\right)_{2}-\mathrm{C}\right), 18.6\left(\left(\mathrm{CH}_{3}\right)_{2}-\mathrm{CH}\right),-2.5\left(\left(\mathrm{CH}_{3}\right)_{2}-\mathrm{Si}\right) \mathrm{ppm}$; HRMS (EI) Calcd. for $\mathrm{C}_{16} \mathrm{H}_{27} \mathrm{SiOBr}[\mathrm{M}]^{+}=342.1014$; Found: 342.1017 .

\subsubsection{General Procedure for the Synthesis of the Compounds, 11a-11d}

A. Nitrogen alkylation

Conventional method. $6 \mathrm{mmol}$ of the respective secondary amine (11a: isoindoline, 11b: pyrrolidine, 11c: morpholine, 11d: octahydroisoindole) were dissolved in anhydrous EtOH ( $3 \mathrm{~mL})$. Then, $206 \mathrm{mg}$ $(0.6 \mathrm{mmol}$ ) of 9 (dissolved in $1 \mathrm{~mL}$ anhydrous EtOH) were added and the mixture was refluxed for $72 \mathrm{~h}$. The solvent was evaporated to dryness to give a residue (10a-10d), which was used in the following deprotection step without further purification.

Proton-sponge ${ }^{\circledR}$ method. $275 \mathrm{mg}(0.8 \mathrm{mmol})$ of 9 (dissolved in $4 \mathrm{~mL}$ anhydrous $\mathrm{CH}_{3} \mathrm{CN}$ ) were mixed with a stirred solution of $120 \mathrm{mg}(0.8 \mathrm{mmol})$ of $\mathrm{NaI}$ and $171 \mathrm{mg}(0.8 \mathrm{mmol})$ of proton-sponge ${ }^{\circledR}$ in anhydrous $\mathrm{CH}_{3} \mathrm{CN}(3 \mathrm{~mL})$. Then, $1.6 \mathrm{mmol}$ of the respective secondary amine were added and the mixture was refluxed for $20 \mathrm{~h}$. The solvent was evaporated to dryness to give a residue (10a-10d), which was used in the following deprotection step without further purification.

\section{B. Removal of the TDS-protecting group}

LiOH-hydrate $(126 \mathrm{mg}, 3.0 \mathrm{mmol})$ was added to a solution of the TDS ether $(\mathbf{1 0 a}-\mathbf{d}, 1 \mathrm{mmol})$ in anhydrous DMF $(2 \mathrm{~mL})$ and the mixture was stirred at ambient temperature until TLC showed complete consumption of the starting material $(3-17 \mathrm{~h})$. The reaction mixture was then diluted with $\mathrm{H}_{2} \mathrm{O}(15 \mathrm{~mL})$, neutralised with phosphate buffer $(\mathrm{pH}=6.4)$, and extracted several times with EtOAc. The combined organic layers were dried over $\mathrm{Na}_{2} \mathrm{SO}_{4}$ and concentrated in vacuo to give a residue, which was purified by flash chromatography.

$\mathrm{N}-(4-H y d r o x y p h e n e t h y l)$ isoindoline (11a). Compound 11a was prepared from 9 via 10a as a white amorphous solid and purified by flash chromatography using $\mathrm{CH} / \mathrm{EtOAc}$ (1:3). Yield: $60 \%$ (proton-sponge ${ }^{\circledR}$ method), $0 \%$ (conventional method); $R_{\mathrm{f}}=0.30(\mathrm{CH}: \mathrm{EtOAC}=1: 3) ;{ }^{1} \mathrm{H}-\mathrm{NMR}(400 \mathrm{MHz}$, DMSO- $\left.d_{6}\right) \delta 9.15(\mathrm{~s}, 1 \mathrm{H}, 4-\mathrm{OH}), 7.24-7.16(\mathrm{~m}, 4 \mathrm{H}, \mathrm{ArH}), 7.05(\mathrm{~d}, J=8.4 \mathrm{~Hz}, 2 \mathrm{H}, \mathrm{H}-2 / 6), 6.67(\mathrm{~d}, J=8.3 \mathrm{~Hz}$, 2H, H-3/5), 3.87 (s, 4H, CH $2-\mathrm{N}), 2.86-2.81(\mathrm{~m}, 2 \mathrm{H}, \mathrm{H}-8), 2.69(\mathrm{t}, J=7.7 \mathrm{~Hz}, 2 \mathrm{H}, \mathrm{H}-7)$ ppm; ${ }^{13} \mathrm{C}-\mathrm{NMR}$ (100 MHz, DMSO- $\left.d_{6}\right) \delta 155.9$ (C-4), 140.5 (ArC), 130.7 (C-1), 129.9 (C-2/6), 127.0 (ArC), 122.6 (ArC), 
$115.4(\mathrm{C}-3 / 5), 58.9\left(\mathrm{CH}_{2}-\mathrm{N}\right), 57.9(\mathrm{C}-8), 34.3$ (C-7) ppm; HRMS (EI) calcd. for $\mathrm{C}_{16} \mathrm{H}_{17} \mathrm{NO}[\mathrm{M}]^{+}=239.1310$; Found: 239.1303.

N-(4-Hydroxyphenethyl)pyrrolidine (11b). Compound $\mathbf{1 1 b}$ was prepared from $\mathbf{9}$ via $\mathbf{1 0 b}$ as a white amorphous solid and purified by flash chromatography using $\mathrm{CHCl}_{3} / \mathrm{MeOH}(1: 1)$. Yield: $81 \%$ (proton-sponge ${ }^{\circledR}$ method), $86 \%$ (conventional method); $R_{\mathrm{f}}=0.22\left(\mathrm{CHCl}_{3}: \mathrm{MeOH}=1: 1\right) ;{ }^{1} \mathrm{H}-\mathrm{NMR}$ $\left(400 \mathrm{MHz}, \mathrm{CDCl}_{3}\right) \delta 6.99$ (d, J = 8.3 Hz, 2H, H-2/6), 6.63 (d, J = $\left.8.3 \mathrm{~Hz}, 2 \mathrm{H}, \mathrm{H}-3 / 5\right), 2.75$ (s, 4H, H-7/8), 2.69-2.62 (m, 4H, $\left.\mathrm{CH}_{2}-\mathrm{N}\right), 1.88-1.79\left(\mathrm{~m}, 4 \mathrm{H}, \mathrm{CH}_{2}-\mathrm{CH}_{2}-\mathrm{N}\right) \mathrm{ppm} ;{ }^{13} \mathrm{C}-\mathrm{NMR}\left(100 \mathrm{MHz}, \mathrm{CDCl}_{3}\right) \delta 155.2$ (C-4), $130.6(\mathrm{C}-1), 129.5(\mathrm{C}-2 / 6), 115.7(\mathrm{C}-3 / 5), 58.6(\mathrm{C}-8), 54.0\left(\mathrm{CH}_{2}-\mathrm{N}\right), 34.2(\mathrm{C}-7), 23.3\left(\mathrm{CH}_{2}-\mathrm{CH}_{2}-\mathrm{N}\right)$ ppm; HRMS (EI) calcd. for $\mathrm{C}_{12} \mathrm{H}_{17} \mathrm{NO}[\mathrm{M}]^{+}=191.1310$; Found: 191.1304.

$\mathrm{N}$-(4-Hydroxyphenethyl)morpholine (11c). Compound 11c was prepared from 9 via 10c as a white amorphous solid and purified by flash chromatography using $\mathrm{CHCl}_{3} / \mathrm{MeOH}$ (15:1). Yield: $87 \%$ (proton-sponge ${ }^{\circledR}$ method), 87\% (conventional method); $R_{\mathrm{f}}=0.27 \mathrm{CHCl}_{3}: \mathrm{MeOH}(15: 1) ;{ }^{1} \mathrm{H}-\mathrm{NMR}$ $\left(400 \mathrm{MHz}, \mathrm{DMSO}-d_{6}\right) \delta 9.14(\mathrm{~s}, 1 \mathrm{H}, 4-\mathrm{OH}), 6.99(\mathrm{~d}, J=8.5 \mathrm{~Hz}, 2 \mathrm{H}, \mathrm{H}-2 / 6), 6.65(\mathrm{~d}, J=8.5 \mathrm{~Hz}, 2 \mathrm{H}$, $\mathrm{H}-3 / 5), 3.56\left(\mathrm{t}, J=4.6 \mathrm{~Hz}, 4 \mathrm{H}, \mathrm{CH}_{2}-\mathrm{O}\right), 2.62-2.57(\mathrm{~m}, 2 \mathrm{H}, \mathrm{H}-7), 2.44-2.39(\mathrm{~m}, 2 \mathrm{H}, \mathrm{H}-8), 2.41-2.35(\mathrm{~m}, 4 \mathrm{H}$, $\mathrm{CH}_{2}-\mathrm{N}$ ) ppm; ${ }^{13} \mathrm{C}-\mathrm{NMR}\left(100 \mathrm{MHz}\right.$, DMSO- $\left.d_{6}\right) \delta 155.9$ (C-4), 130.7 (C-1), 129.9 (C-2/6), 115.5 (C-3/5), $66.6\left(\mathrm{CH}_{2}-\mathrm{O}\right), 61.1(\mathrm{C}-8), 53.8\left(\mathrm{CH}_{2}-\mathrm{N}\right), 32.1(\mathrm{C}-7)$ ppm; HRMS (EI) calcd. for $\mathrm{C}_{12} \mathrm{H}_{17} \mathrm{NO}_{2}[\mathrm{M}]^{+}=$ 207.1259; Found: 207.1255.

$\mathrm{N}$-(4-Hydroxyphenethyl)octahydroisoindole (11d). Compound 11d was prepared from 9 via 10d as a white amorphous solid and purified by flash chromatography using $\mathrm{CHCl}_{3} / \mathrm{EtOH}$ (5:2). Yield: $77 \%$ (proton-sponge ${ }^{\circledR}$ method), 79\% (conventional method); $R_{\mathrm{f}}=0.19\left(\mathrm{CHCl}_{3}: \mathrm{EtOH}=5: 2\right) ;{ }^{1} \mathrm{H}-\mathrm{NMR}$ $\left(400 \mathrm{MHz}, \mathrm{CDCl}_{3}\right) \delta 6.93(\mathrm{~d}, J=8.3 \mathrm{~Hz}, 2 \mathrm{H}, \mathrm{H}-2 / 6), 6.77(\mathrm{~d}, J=8.3 \mathrm{~Hz}, 2 \mathrm{H}, \mathrm{C}-3 / 5), 3.18(\mathrm{dd}, J=10.7$, $\left.6.3 \mathrm{~Hz}, 2 \mathrm{H}, \mathrm{CH}_{2(\mathrm{a})}-\mathrm{N}\right), 3.06-3.00(\mathrm{~m}, 2 \mathrm{H}, \mathrm{H}-8), 2.93-2.87\left(\mathrm{~m}, 2 \mathrm{H}, \mathrm{CH}_{2(\mathrm{~b})}-\mathrm{N}\right), 2.86-2.80(\mathrm{~m}, 2 \mathrm{H}, \mathrm{H}-7)$, 2.34-2.24 (m, 2H, CH-CH $), 1.67-1.58\left(\mathrm{~m}, 2 \mathrm{H}, \mathrm{CH}_{2(\mathrm{a})}-\mathrm{CH}\right), 1.54-1.45\left(\mathrm{~m}, 2 \mathrm{H}, \mathrm{CH}_{2(\mathrm{a})}-\mathrm{CH}_{2}-\mathrm{CH}\right), 1.52-1.43$ (m, 2H, $\left.\mathrm{CH}_{2(\mathrm{~b})}-\mathrm{CH}\right), 1.39-1.31\left(\mathrm{~m}, 2 \mathrm{H}, \mathrm{CH}_{2(\mathrm{~b})}-\mathrm{CH}_{2}-\mathrm{CH}\right) \mathrm{ppm} ;{ }^{13} \mathrm{C}-\mathrm{NMR}\left(100 \mathrm{MHz}, \mathrm{CDCl}_{3}\right) \delta 156.4$ (C-4), $129.5(\mathrm{C}-2 / 6), 128.1(\mathrm{C}-1), 115.9(\mathrm{C}-3 / 5), 59.0(\mathrm{C}-8), 57.1\left(\mathrm{CH}_{2}-\mathrm{N}\right), 36.7\left(\mathrm{CH}-\mathrm{CH}_{2}\right), 32.3(\mathrm{C}-7), 25.9$ $\left(\mathrm{CH}_{2}-\mathrm{CH}\right), 22.5\left(\mathrm{CH}_{2}-\mathrm{CH}_{2}-\mathrm{CH}\right)$ ppm; HRMS (EI) calcd. for $\mathrm{C}_{16} \mathrm{H}_{23} \mathrm{NO}[\mathrm{M}]^{+}=245.1780$; Found: 245.1772 .

$\mathrm{N}$-(4-Hydroxyphenethyl)-4,5,6,7-tetrahydroisoindole (11e). A mixture of 11a (239 mg, $1 \mathrm{mmol})$, ammonium formate $(631 \mathrm{mg}, 10 \mathrm{mmol})$, and palladium hydroxide on carbon, $20 \mathrm{wt}$. \% loading $(64 \mathrm{mg})$ in anhydrous $\mathrm{MeOH}(8 \mathrm{~mL})$ was refluxed for 16 hrs. The mixture was filtered through celite ${ }^{\circledR}$, diluted with $\mathrm{H}_{2} \mathrm{O}$, and extracted three times with EtOAc. The combined organic layers were dried over $\mathrm{Na}_{2} \mathrm{SO}_{4}$ and concentrated in vacuo to give $241 \mathrm{mg}$ of crude 11e as a slightly yellow oil in quantitative yields, which can be used without further purification. $R_{\mathrm{f}}=0.69$ (EtOAc); ${ }^{1} \mathrm{H}-\mathrm{NMR}\left(400 \mathrm{MHz}, \mathrm{CDCl}_{3}\right) \delta 7.00(\mathrm{~d}, J=$ $8.2 \mathrm{~Hz}, 2 \mathrm{H}, \mathrm{H}-2 / 6), 6.75$ (d, J = 8.2 Hz, 2H, H-3/5), 6.31 (s, 2H, CH-N), 3.97-3.91 (m, 2H, H-8), 3.01-2.90 (m, 2H, H-7), 2.59-2.52 (m, 4H, $\left.\mathrm{CH}_{2}-\mathrm{C}=\right), 1.76-1.68\left(\mathrm{~m}, 4 \mathrm{H}, \mathrm{CH}_{2}-\mathrm{CH}_{2}-\mathrm{C}=\right)$ ppm; ${ }^{13} \mathrm{C}-\mathrm{NMR}(100 \mathrm{MHz}$, $\left.\mathrm{CDCl}_{3}\right) \delta 154.3(\mathrm{C}-4), 130.7(\mathrm{C}-1), 129.8(\mathrm{C}-2 / 6), 119.4(\mathrm{C}=\mathrm{C}(\mathrm{H})-\mathrm{N}), 115.9(\mathrm{CH}-\mathrm{N}), 115.4(\mathrm{C}-3 / 5), 51.3$ (C-8), $37.6(\mathrm{C}-7), 24.2\left(\mathrm{CH}_{2}-\mathrm{CH}_{2}-\mathrm{C}=\right), 22.0\left(\mathrm{CH}_{2}-\mathrm{C}=\right)$ ppm; HRMS (EI) calcd. for $\mathrm{C}_{16} \mathrm{H}_{19} \mathrm{NO}[\mathrm{M}]^{+}=$ 241.1467; Found: 241.1465.

\subsubsection{General Procedure for the Reduction of Heterocyclic N-Imides}

The corresponding imide, $7 \mathbf{a} / 7 \mathbf{h},(2 \mathrm{mmol})$ was dissolved in $8 \mathrm{~mL}$ of anhydrous THF and then treated dropwise with $4 \mathrm{~mL} \mathrm{LiAlH}_{4}\left(1 \mathrm{M}\right.$ solution in THF) at $0{ }^{\circ} \mathrm{C}$. After the addition of $\mathrm{LiAlH}_{4}$ was complete, the reaction was allowed to reach an ambient temperature for $2 \mathrm{~h}$. Then, a $2 \mathrm{M}$ aqueous solution of $\mathrm{Na} / \mathrm{K}$ tartrate $(50 \mathrm{~mL})$ was added at $0{ }^{\circ} \mathrm{C}$ to quench the reaction and the mixture was stirred for $1 \mathrm{~h}$. The solution was extracted four times with MTBE, the combined organic layers were dried over $\mathrm{Na}_{2} \mathrm{SO}_{4}$, and concentrated in vacuo to give a residue, which was purified by flash chromatography. 
$\mathrm{N}$-(4-Hydroxyphenethyl)isoindoline (11a). Compound 11a was prepared from 7a as a white amorphous solid and purified by flash chromatography using $\mathrm{CH} / \mathrm{EtOAc}(1: 3)$. Yield: $72 \% ; R_{\mathrm{f}}=0.30$ (CH:EtOAC $=1: 3)$.

3-Hydroxy-N-(4-hydroxyphenethyl)octahydroisoindole-1-one (12). Compound 12 was prepared from $7 \mathrm{~h}$ as a white amorphous solid and purified by flash chromatography using $\mathrm{CH} / \mathrm{EtOAc}$ (1:3). Yield: 88\%; $R_{\mathrm{f}}=0.28(\mathrm{CH}: \mathrm{EtOAc}=1: 3) ; \mathrm{HRMS}(\mathrm{EI})$ calcd. for $\mathrm{C}_{16} \mathrm{H}_{21} \mathrm{NO}_{3}[\mathrm{M}]^{+}=275.1521$; Found: 275.1527.

\subsubsection{Procedures for the Synthesis of Dienones, 13a-j, 14a, 14c, 15}

Conventional method. A solution of the cyclic imide, $7 \mathbf{a}-\mathbf{j}$, or amide, $\mathbf{1 2},(1.5 \mathrm{mmol})$ in $\mathrm{CH}_{3} \mathrm{CN}(20 \mathrm{~mL})$ and $\mathrm{H}_{2} \mathrm{O}(8 \mathrm{~mL})$ at $0{ }^{\circ} \mathrm{C}$ was treated with PIDA (644 mg, $\left.2.0 \mathrm{mmol}\right)$, and stirred for $7 \mathrm{~min}$ at this temperature. The reaction mixture was diluted with EtOAc and washed with a $1 \mathrm{M}$ aqueous solution of $\mathrm{NaHCO}_{3}$. The aqueous phase was re-extracted three times with EtOAc. The combined organic layers were dried over $\mathrm{Na}_{2} \mathrm{SO}_{4}$ and concentrated in vacuo to give a residue, which was purified by flash chromatography.

Phosphate buffer method. $1 \mathrm{mmol}$ of the respective tertiary amine, 11a/11c, was dissolved in $1.5 \mathrm{~mL} \mathrm{HCl}$ ( $1 \mathrm{M}$ in dioxane) and concentrated in vacuo to yield the corresponding hydrochloride. A solution of the hydrochloride in $\mathrm{CH}_{3} \mathrm{CN}(12 \mathrm{~mL}), \mathrm{H}_{2} \mathrm{O}(3 \mathrm{~mL})$ and phosphate buffer $(1 \mathrm{M}, \mathrm{pH}=6.4,2 \mathrm{~mL})$ at $0{ }^{\circ} \mathrm{C}$ was then treated with PIDA $(644 \mathrm{mg}, 2.0 \mathrm{mmol})$ and stirred for $7 \mathrm{~min}$ at this temperature. The solvent was evaporated to dryness, and the crude product was purified by flash chromatography.

N-[2-(1-Hydroxy-4-oxocyclohexa-2,5-dien-1-yl)ethyl]phthalimide (13a). Compound 13a was prepared from $7 \mathbf{a}$ as white crystals and purified by flash chromatography using $\mathrm{CH} / \mathrm{EtOAc}(1: 3)$. Yield: $67 \% ; R_{\mathrm{f}}=0.42$ $(\mathrm{CH}: \mathrm{EtOAc}=1: 3) ;$ m.p.: $161-162{ }^{\circ} \mathrm{C} ;{ }^{1} \mathrm{H}-\mathrm{NMR}\left(300 \mathrm{MHz}, \mathrm{DMSO}-d_{6}\right) \delta 7.88-7.80(\mathrm{~m}, 4 \mathrm{H}, \mathrm{ArH}), 6.97(\mathrm{~d}$, $J=10.2 \mathrm{~Hz}, 2 \mathrm{H}, \mathrm{H}-2 / 6), 6.10$ (d, $J=10.2 \mathrm{~Hz}, 2 \mathrm{H}, \mathrm{H}-3 / 5), 5.88$ (s, 1H, 1-OH), 3.68-3.50 (m, 2H, H-8), 2.08-1.88 (m, 2H, H-7) ppm; ${ }^{13} \mathrm{C}-\mathrm{NMR}\left(100 \mathrm{MHz}, \mathrm{DMSO}-d_{6}\right) \delta 185.0(\mathrm{C}-4), 167.7((\mathrm{CO}) \mathrm{N}), 152.2(\mathrm{C}-2 / 6)$, 134.4 (ArC), 131.7 (ArC), 127.1 (C-3/5), 123.0 (ArC), 67.5 (C-1), 37.8 (C-7), 33.1 (C-8) ppm; HRMS (EI) calcd. for $\mathrm{C}_{16} \mathrm{H}_{13} \mathrm{NO}_{4}[\mathrm{M}]^{+}=283.0845$; Found: 283.0845 .

N-[2-(1-Hydroxy-4-oxocyclohexa-2,5-dien-1-yl)ethyl]maleimide (13b). Compound $\mathbf{1 3 b}$ was prepared from $7 \mathbf{b}$ as yellow crystals and purified by flash chromatography using $\mathrm{CH} / \mathrm{EtOAc}(1: 5)$. Yield: $17 \% ; R_{\mathrm{f}}=$ $0.40(\mathrm{CH}: \mathrm{EtOAc}=1: 5) ;$ m.p.: $151-152{ }^{\circ} \mathrm{C} ;{ }^{1} \mathrm{H}-\mathrm{NMR}\left(300 \mathrm{MHz}, \mathrm{DMSO}-d_{6}\right) \delta 6.99(\mathrm{~s}, 2 \mathrm{H}, \mathrm{CH}-(\mathrm{CO}) \mathrm{N})$, $6.91(\mathrm{~d}, J=10.1 \mathrm{~Hz}, 2 \mathrm{H}, \mathrm{H}-2 / 6), 6.08(\mathrm{~d}, J=10.1 \mathrm{~Hz}, 2 \mathrm{H}, \mathrm{H}-3 / 5), 5.85(\mathrm{~s}, 1 \mathrm{H}, 1-\mathrm{OH}), 3.45-3.38(\mathrm{~m}, 2 \mathrm{H}$, H-8), 1.93-1.85 (m, 2H, H-7) ppm; ${ }^{13} \mathrm{C}-\mathrm{NMR}\left(100 \mathrm{MHz}, \mathrm{DMSO}-d_{6}\right) \delta 185.0(\mathrm{C}-4), 170.8((\mathrm{CO}) \mathrm{N}), 152.1$ (C-2/6), 134.6 (CH-(CO)N), 127.1 (C-3/5), 67.4 (C-1), 37.9 (C-7), 32.8 (C-8) ppm; HRMS (EI) calcd. for $\mathrm{C}_{12} \mathrm{H}_{11} \mathrm{NO}_{4}[\mathrm{M}]^{+}=233.0688$; Found: 233.0686 .

N-[2-(1-Hydroxy-4-oxocyclohexa-2,5-dien-1-yl)ethyl]succinimide (13c). Compound 13c was prepared from $7 \mathrm{c}$ as a white solid and purified by flash chromatography using $\mathrm{CHCl}_{3} / \mathrm{CH}_{3} \mathrm{CN}(1: 3)$. Yield: $55 \% ; R_{\mathrm{f}}=$ $0.51\left(\mathrm{CHCl}_{3}: \mathrm{CH}_{3} \mathrm{CN}=1: 3\right)$; m.p.: $128-129{ }^{\circ} \mathrm{C} ;{ }^{1} \mathrm{H}-\mathrm{NMR}\left(400 \mathrm{MHz}, \mathrm{DMSO}-d_{6}\right) \delta 6.93(\mathrm{~d}, J=10.2 \mathrm{~Hz}, 2 \mathrm{H}$, $\mathrm{H}-2 / 6), 6.10(\mathrm{~d}, J=10.2 \mathrm{~Hz}, 2 \mathrm{H}, \mathrm{H}-3 / 5), 5.86(\mathrm{~s}, 1 \mathrm{H}, 1-\mathrm{OH}), 2.57\left(\mathrm{~s} \mathrm{br}, 4 \mathrm{H}, \mathrm{CH}_{2}-(\mathrm{CO}) \mathrm{N}\right), 3.38-3.31(\mathrm{~m}$, 2H, H-8), 1.89-1.77 (m, 2H, H-7) ppm; ${ }^{13} \mathrm{C}-\mathrm{NMR}\left(100 \mathrm{MHz}, \mathrm{DMSO}-d_{6}\right) \delta 185.5(\mathrm{C}-4), 178.0((\mathrm{CO}) \mathrm{N})$, $152.6(\mathrm{C}-2 / 6), 127.5(\mathrm{C}-3 / 5), 67.9(\mathrm{C}-1), 37.5(\mathrm{C}-7), 33.9(\mathrm{C}-8), 28.4\left(\mathrm{CH}_{2}-(\mathrm{CO}) \mathrm{N}\right) \mathrm{ppm}$; HRMS (EI) calcd. for $\mathrm{C}_{12} \mathrm{H}_{13} \mathrm{NO}_{4}[\mathrm{M}]^{+}=235.0845$; Found: 235.0826.

4,5-Dichloro-N-[2-(1-hydroxy-4-oxocyclohexa-2,5-dien-1-yl)ethyl]phthalimide (13d). Compound 13d was prepared from $\mathbf{7 d}$ as white crystals and purified by flash chromatography using CH/EtOAc (1:1). Yield: $40 \% ; R_{\mathrm{f}}=0.22(\mathrm{CH}: \mathrm{EtOAc}=1: 1)$; m.p.: $213-214{ }^{\circ} \mathrm{C} ;{ }^{1} \mathrm{H}-\mathrm{NMR}\left(400 \mathrm{MHz}\right.$, DMSO- $\left.d_{6}\right) \delta 8.17(\mathrm{~s}, 2 \mathrm{H}$, $\mathrm{ArH}), 6.96(\mathrm{~d}, J=10.1 \mathrm{~Hz}, 2 \mathrm{H}, \mathrm{H}-2 / 6), 6.10(\mathrm{~d}, J=10.1 \mathrm{~Hz}, 2 \mathrm{H}, \mathrm{H}-3 / 5), 5.89(\mathrm{~s}, 1 \mathrm{H}, 1-\mathrm{OH}), 3.62-3.56$ (m, 2H, H-8), 2.02-1.95 (m, 2H, H-7) ppm; ${ }^{13} \mathrm{C}-\mathrm{NMR}\left(100 \mathrm{MHz}, \mathrm{DMSO}-d_{6}\right) \delta 185.5(\mathrm{C}-4), 166.4((\mathrm{CO}) \mathrm{N})$, 152.6 (C-2/6), $137.7(\mathrm{C}(\mathrm{Cl})=), 132.1(\mathrm{C}=\mathrm{C}(\mathrm{CO}) \mathrm{N}), 127.6(\mathrm{C}-3 / 5), 125.6(\mathrm{ArC}), 67.9(\mathrm{C}-1), 38.0(\mathrm{C}-7), 34.0$ (C-8) ppm; HRMS (EI) calcd. for $\mathrm{C}_{16} \mathrm{H}_{11} \mathrm{Cl}_{2} \mathrm{NO}_{4}[\mathrm{M}]^{+}=351.0065$; Found: 351.0090 . 
3,4-Dichloro-N-[2-(1-hydroxy-4-oxocyclohexa-2,5-dien-1-yl)ethyl]maleimide (13e). Compound 13e was prepared from $7 \mathbf{e}$ as yellowish crystals and purified by flash chromatography using CH/EtOAc (1:1). Yield: $64 \% ; R_{\mathrm{f}}=0.30(\mathrm{CH}: \mathrm{EtOAc}=1: 1) ;$ m.p.: $168-169{ }^{\circ} \mathrm{C} ;{ }^{1} \mathrm{H}-\mathrm{NMR}\left(400 \mathrm{MHz}, \mathrm{DMSO}-d_{6}\right) \delta 6.95$ (d, $J=10.1 \mathrm{~Hz}, 2 \mathrm{H}, \mathrm{H}-2 / 6), 6.11$ (d, $J=10.1 \mathrm{~Hz}, 2 \mathrm{H}, \mathrm{H}-3 / 5), 5.91$ (s br, 1H, 1-OH), 3.53-3.46 (m, 2H, H-8), 1.95-1.90 (m, 2H, H-7) ppm; ${ }^{13} \mathrm{C}-\mathrm{NMR}\left(100 \mathrm{MHz}, \mathrm{DMSO}-d_{6}\right) \delta 185.4(\mathrm{C}-4), 163.3((\mathrm{CO}) \mathrm{N}), 152.5$ (C-2/6), $132.9(\mathrm{C}(\mathrm{Cl})=), 127.6$ (C-3/5), 67.8 (C-1), 37.9 (C-7), 34.8 (C-8) ppm; HRMS (EI) calcd. for $\mathrm{C}_{12} \mathrm{H}_{9} \mathrm{Cl}_{2} \mathrm{NO}_{4}[\mathrm{M}]^{+}=300.9909 ;$ Found: 300.9914 .

N-[2-(1-Hydroxy-4-oxocyclohexa-2,5-dien-1-yl)ethyl]pyridine-2,3-dicarboximide (13f). Compound 13f was prepared from $\mathbf{7 f}$ as white crystals and purified by flash chromatography using $\mathrm{CHCl}_{3} / \mathrm{CH}_{3} \mathrm{CN}(1: 1)$. Yield: $19 \% ; R_{\mathrm{f}}=0.37\left(\mathrm{CHCl}_{3}: \mathrm{CH}_{3} \mathrm{CN}=1: 1\right)$; m.p.: $167-168{ }^{\circ} \mathrm{C} ;{ }^{1} \mathrm{H}-\mathrm{NMR}\left(400 \mathrm{MHz}\right.$, DMSO-d $\left.d_{6}\right) \delta 8.95$ $(\mathrm{dd}, J=5.0,1.5 \mathrm{~Hz}, 1 \mathrm{H}, \mathrm{ArH}), 8.27(\mathrm{dd}, J=7.7,1.5 \mathrm{~Hz}, 1 \mathrm{H}, \mathrm{ArH}), 7.77(\mathrm{dd}, J=7.7,5.0 \mathrm{~Hz}, 1 \mathrm{H}, \mathrm{ArH})$, $6.98(\mathrm{~d}, J=10.1 \mathrm{~Hz}, 2 \mathrm{H}, \mathrm{C}-2 / 6), 6.11(\mathrm{~d}, J=10.1,2 \mathrm{H}, \mathrm{H}-3 / 5), 5.88$ (s, 1H, 1-OH), 3.69-3.57 (m, 2H, C-8), 2.05-1.94 (m, 2H, H-7) ppm; ${ }^{13} \mathrm{C}-\mathrm{NMR}\left(100 \mathrm{MHz}, \mathrm{DMSO}-d_{6}\right) \delta 185.5(\mathrm{C}-4), 166.6((\mathrm{CO}) \mathrm{N}), 155.2(\mathrm{ArC})$, 152.6 (C-2/6), 152.0 (ArC), 131.6 (ArC), 128.3 (ArC), 127.7 (ArC), 127.6 (C-3/5), 68.0 (C-1), 38.1 (C-7), 33.7 (C-8) ppm; HRMS (EI) calcd. for $\mathrm{C}_{15} \mathrm{H}_{12} \mathrm{~N}_{2} \mathrm{O}_{4}$ [M] ${ }^{+}=284.0797$; Found: 284.0792 .

N-[2-(1-Hydroxy-4-oxocyclohexa-2,5-dien-1-yl)ethyl]morpholine-3,5-dione (13g). Compound 13g was prepared from $7 \mathrm{~g}$ as a yellowish solid and purified by flash chromatography using $\mathrm{CH} / \mathrm{EtOAc}$ (1:5). Yield: $18 \% ; R_{\mathrm{f}}=0.33\left(\mathrm{CHCl}_{3}:\right.$ EtOAc $\left.=1: 5\right) ;$ m.p.: $142-143{ }^{\circ} \mathrm{C} ;{ }^{1} \mathrm{H}-\mathrm{NMR}\left(400 \mathrm{MHz}, \mathrm{DMSO}-d_{6}\right) \delta$ $6.94(\mathrm{~d}, J=10.1 \mathrm{~Hz}, 2 \mathrm{H}, \mathrm{H}-2 / 6), 6.12(\mathrm{~d}, J=10.0 \mathrm{~Hz}, 2 \mathrm{H}, \mathrm{H}-3 / 5), 4.36\left(\mathrm{~s}, 4 \mathrm{H}, \mathrm{CH}_{2}-(\mathrm{CO}) \mathrm{N}\right), 3.70-3.56(\mathrm{~m}$, 2H, H-8), 1.89-1.78 (m, 2H, H-7) ppm; ${ }^{13} \mathrm{C}-\mathrm{NMR}\left(100 \mathrm{MHz}, \mathrm{DMSO}-d_{6}\right) \delta 185.5(\mathrm{C}-4), 170.1((\mathrm{CO}) \mathrm{N})$, 152.7 (C-2/6), 127.5 (C-3/5), 68.0 (C-1), $67.4\left(\mathrm{CH}_{2}-(\mathrm{CO}) \mathrm{N}\right), 37.8$ (C-7), 33.8 (C-8) ppm; HRMS (EI) calcd. for $\mathrm{C}_{12} \mathrm{H}_{13} \mathrm{NO}_{5}[\mathrm{M}]^{+}=251.0794$; Found: 251.0794 .

N-[2-(1-Hydroxy-4-oxocyclohexa-2,5-dien-1-yl)ethyl]hexahydrophthalimide (13h). Compound 13h was prepared from $7 \mathrm{~h}$ as yellow crystals and purified by flash chromatography using $\mathrm{CH} / \mathrm{EtOAc}(1: 3)$. Yield: $79 \% ; R_{\mathrm{f}}=0.29(\mathrm{CH}: \mathrm{EtOAc}=1: 3)$; m.p.: $135-136{ }^{\circ} \mathrm{C} ;{ }^{1} \mathrm{H}-\mathrm{NMR}\left(400 \mathrm{MHz}, \mathrm{DMSO}-d_{6}\right) \delta 6.94$ $(\mathrm{d}, J=10.1 \mathrm{~Hz}, 2 \mathrm{H}, \mathrm{H}-2 / 6), 6.10(\mathrm{~d}, J=10.1 \mathrm{~Hz}, 2 \mathrm{H}, \mathrm{H}-3 / 5), 5.84(\mathrm{~s}, 1 \mathrm{H}, 1-\mathrm{OH}), 3.40-3.35(\mathrm{~m}, 2 \mathrm{H}$, $\mathrm{H}-8), 2.93-2.82(\mathrm{~m}, 2 \mathrm{H}, \mathrm{CH}-(\mathrm{CO}) \mathrm{N}), 1.85-1.80(\mathrm{~m}, 2 \mathrm{H}, \mathrm{H}-7), 1.71\left(\mathrm{~s}, 2 \mathrm{H}, \mathrm{CH}_{2(\mathrm{a})}-\mathrm{CH}\right), 1.60-1.51(\mathrm{~m}, 2 \mathrm{H}$, $\left.\mathrm{CH}_{2(\mathrm{~b})}-\mathrm{CH}\right), 1.42-1.32$ (m, 2H, $\left.\mathrm{CH}_{2(\mathrm{a})}-\mathrm{CH}_{2}-\mathrm{CH}\right), 1.31-1.21$ (m, 2H, $\left.\mathrm{CH}_{2(\mathrm{~b})}-\mathrm{CH}_{2}-\mathrm{CH}\right)$ ppm; ${ }^{13} \mathrm{C}-\mathrm{NMR}(100$ $\left.\mathrm{MHz}, \mathrm{DMSO}-d_{6}\right) \delta 185.4(\mathrm{C}-4), 179.7((\mathrm{CO}) \mathrm{N}), 152.7(\mathrm{C}-2 / 6), 127.5(\mathrm{C}-3 / 5), 67.9(\mathrm{C}-1), 39.3(\mathrm{CH}-(\mathrm{CO}) \mathrm{N})$, 37.6 (C-7), $33.8(\mathrm{C}-8), 23.5\left(\mathrm{CH}_{2}-\mathrm{CH}\right), 21.6\left(\mathrm{CH}_{2}-\mathrm{CH}_{2}-\mathrm{CH}\right)$ ppm; HRMS (EI) calcd. for $\mathrm{C}_{16} \mathrm{H}_{19} \mathrm{NO}_{4}$ $[\mathrm{M}]^{+}=289.1314 ;$ Found: 289.1310 .

$\mathrm{N}$-[2-(1-Hydroxy-4-oxocyclohexa-2,5-dien-1-yl)ethyl]-3,4,5,6-tetrahydrophthalimide (13i). Compound 13i was prepared from $\mathbf{7 i}$ as an orange solid and purified by flash chromatography using $\mathrm{CH} / \mathrm{EtOAc}$ (1:1). Yield: $88 \% ; R_{\mathrm{f}}=0.18(\mathrm{CH}: \mathrm{EtOAc}=1: 1)$; m.p.: $93-94{ }^{\circ} \mathrm{C} ;{ }^{1} \mathrm{H}-\mathrm{NMR}\left(400 \mathrm{MHz}, \mathrm{DMSO}-d_{6}\right) \delta 6.92(\mathrm{~d}$, $J=10.1 \mathrm{~Hz}, 2 \mathrm{H}, \mathrm{H}-2 / 6), 6.08$ (d, $J=10.1 \mathrm{~Hz}, 2 \mathrm{H}, \mathrm{H}-3 / 5), 5.85(\mathrm{~s}, 1 \mathrm{H}, 1-\mathrm{OH}), 3.42-3.36(\mathrm{~m}, 2 \mathrm{H}, \mathrm{H}-8)$, 2.24-2.17 (m, $\left.4 \mathrm{H}, \mathrm{CH}_{2}-\mathrm{C}=\right), 1.86(\mathrm{dd}, J=8.5,6.8 \mathrm{~Hz}, 2 \mathrm{H}, \mathrm{H}-7), 1.69-1.62\left(\mathrm{~m}, 4 \mathrm{H}, \mathrm{CH}_{2}-\mathrm{CH}_{2}-\mathrm{C}=\right)$ ppm; ${ }^{13} \mathrm{C}-\mathrm{NMR}\left(100 \mathrm{MHz}, \mathrm{DMSO}-d_{6}\right) \delta 185.5(\mathrm{C}-4), 170.9((\mathrm{CO}) \mathrm{N}), 152.6(\mathrm{C}-2 / 6), 141.5(\mathrm{C}=\mathrm{C}(\mathrm{CO})), 127.5$ (C-3/5), 67.9 (C-1), 38.6 (C-7), $33.0(\mathrm{C}-8), 21.3\left(\mathrm{CH}_{2}-\mathrm{CH}_{2}-\mathrm{C}=\right), 19.9\left(\mathrm{CH}_{2}-\mathrm{C}=\right)$ ppm; HRMS (EI) calcd. for $\mathrm{C}_{16} \mathrm{H}_{17} \mathrm{NO}_{4}[\mathrm{M}]^{+}=287.1158$; Found: 287.1160 .

N-[2-(1-Hydroxy-4-oxocyclohexa-2,5-dien-1-yl)ethyl]-1,2,3,6-tetrahydrophthalimide (13j). Compound 13j was prepared from $\mathbf{7} \mathbf{j}$ as white crystals and purified by flash chromatography using $\mathrm{CH} / \mathrm{EtOAc}(1: 1)$. Yield: $49 \% ; R_{\mathrm{f}}=0.28(\mathrm{CH}: \mathrm{EtOAc}=1: 1)$; m.p.: $145-146{ }^{\circ} \mathrm{C} ;{ }^{1} \mathrm{H}-\mathrm{NMR}\left(400 \mathrm{MHz}, \mathrm{DMSO}-d_{6}\right) \delta 6.90(\mathrm{~d}, J=$ $10.1 \mathrm{~Hz}, 2 \mathrm{H}, \mathrm{H}-2 / 6), 6.09$ (d, J = $10.1 \mathrm{~Hz}, 2 \mathrm{H}, \mathrm{H}-3 / 5), 5.87$ (s, 1H, 1-OH), 5.85-5.82 (m, 2H, CH=CH), 3.31-3.36 (m, 2H, H-8), 3.11-3.06 (m, 2H, CH- $(\mathrm{CO}) \mathrm{N}), 2.39-2.32\left(\mathrm{~m}, 2 \mathrm{H}, \mathrm{CH}_{2(\mathrm{a})}-\mathrm{CH}\right), 2.21-2.13(\mathrm{~m}, 2 \mathrm{H}$, $\left.\mathrm{CH}_{2(\mathrm{~b})}-\mathrm{CH}\right), 1.79(\mathrm{td}, J=7.5,1.5 \mathrm{~Hz}, 2 \mathrm{H}, \mathrm{H}-7) \mathrm{ppm} ;{ }^{13} \mathrm{C}-\mathrm{NMR}\left(100 \mathrm{MHz}\right.$, DMSO- $\left.d_{6}\right) \delta 185.5(\mathrm{C}-4), 180.3$ $((\mathrm{CO}) \mathrm{N}), 152.5(\mathrm{C}-2 / 6), 128.1(\mathrm{CH}=\mathrm{CH}), 127.6(\mathrm{C}-3 / 5), 67.8(\mathrm{C}-1), 38.9(\mathrm{CH}-(\mathrm{CO}) \mathrm{N}), 37.8(\mathrm{C}-7), 34.1$ (C-8), $23.5\left(\mathrm{CH}_{2}-\mathrm{CH}\right)$ ppm; HRMS (EI) calcd. for $\mathrm{C}_{16} \mathrm{H}_{17} \mathrm{NO}_{4}[\mathrm{M}]^{+}=287.1158$; Found: 287.1154. 
N-[2-(1-Hydroxy-4-oxocyclohexa-2,5-dien-1-yl)ethyl]isoindoline (14a). Compound 14a was prepared from 11a applying the phosphate buffer method as a brownish solid and purified by flash chromatography using $\mathrm{CHCl}_{3} / \mathrm{EtOH}(1: 5)$. Yield: $16 \% ; R_{\mathrm{f}}=0.50\left(\mathrm{CHCl}_{3}: \mathrm{EtOH}=1: 5\right) ;$ m.p.: $103-104{ }^{\circ} \mathrm{C} ;{ }^{1} \mathrm{H}-\mathrm{NMR}$ $\left(400 \mathrm{MHz}, \mathrm{DMSO}-d_{6}\right) \delta 7.24-7.12(\mathrm{~m}, 4 \mathrm{H}, \mathrm{ArH}), 6.99(\mathrm{~d}, J=10.1 \mathrm{~Hz}, 2 \mathrm{H}, \mathrm{H}-2 / 6), 6.06(\mathrm{~d}, J=10.1 \mathrm{~Hz}$, 2H, H-3/5), 3.81-3.77 (m, 4H, CH $-\mathrm{N}), 2.70-2.62$ (m, 2H, H-8), 1.93-1.85 (m, 2H, H-7) ppm; ${ }^{13} \mathrm{C}-\mathrm{NMR}$ $\left(100 \mathrm{MHz}, \mathrm{DMSO}-d_{6}\right) \delta 185.3(\mathrm{C}-4), 153.2(\mathrm{C}-2 / 6), 139.8$ (ArC), 126.5 (ArC), 126.3 (C-3/5) 122.0 (ArC), $68.0(\mathrm{C}-1), 58.3\left(\mathrm{CH}_{2}-\mathrm{N}\right), 50.0$ (C-8), 38.6 (C-7) ppm; HRMS (EI) calcd. for $\mathrm{C}_{16} \mathrm{H}_{17} \mathrm{NO}_{2}[\mathrm{M}]^{+}=255.1259$; Found: 255.1251.

N-[2-(1-Hydroxy-4-oxocyclohexa-2,5-dien-1-yl)ethyl]morpholine (14c). Compound 14c was prepared from 11c applying the phosphate buffer method as a brownish solid and purified by flash chromatography using EtOAc/EtOH (1:1). Yield: $28 \% ; R_{\mathrm{f}}=0.37$ (EtOAc:EtOH = 1:1); m.p.: $98-99{ }^{\circ} \mathrm{C} ;{ }^{1} \mathrm{H}-\mathrm{NMR}(400 \mathrm{MHz}$, DMSO- $\left.d_{6}\right) \delta 6.95(\mathrm{~d}, J=10.0 \mathrm{~Hz}, 2 \mathrm{H}, \mathrm{H}-2 / 6), 6.04(\mathrm{~d}, J=10.0 \mathrm{~Hz}, 2 \mathrm{H}, \mathrm{H}-3 / 5), 3.56-3.46\left(\mathrm{~m}, 4 \mathrm{H}, \mathrm{CH}_{2}-\mathrm{O}\right)$, 2.32-2.26 (m, 4H, CH $-\mathrm{N}), 2.25-2.20(\mathrm{~m}, 2 \mathrm{H}, \mathrm{H}-8), 1.79(\mathrm{t}, J=7.6 \mathrm{~Hz}, 2 \mathrm{H}, \mathrm{H}-7) \mathrm{ppm} ;{ }^{13} \mathrm{C}-\mathrm{NMR}(100 \mathrm{MHz}$, DMSO-d $\left.d_{6}\right) \delta 185.8(\mathrm{C}-4), 153.8(\mathrm{C}-2 / 6), 126.8(\mathrm{C}-3 / 5), 68.5(\mathrm{C}-1), 66.6\left(\mathrm{CH}_{2}-\mathrm{O}\right), 53.7\left(\mathrm{CH}_{2}-\mathrm{N}\right), 53.4(\mathrm{C}-8)$, 37.0 (C-7) ppm; HRMS (EI) calcd. for $\mathrm{C}_{12} \mathrm{H}_{17} \mathrm{NO}_{3}[\mathrm{M}]^{+}=223.1208$; Found: 223.1201.

3-Hydroxy-N-[2-(1-hydroxy-4-oxocyclohexa-2,5-dien-1-yl)ethyl]octahydroisoindole-1-one (15). Compound 15 was prepared from 12 as a beige solid and purified by flash chromatography using EtOAc. Yield: 65\%; $R_{\mathrm{f}}=0.14$ (EtOAc); m.p.: $127-128{ }^{\circ} \mathrm{C} ;{ }^{1} \mathrm{H}-\mathrm{NMR}\left(400 \mathrm{MHz}, \mathrm{DMSO}-d_{6}\right) \delta 6.97-6.91(\mathrm{~m}, 2 \mathrm{H}, \mathrm{H}-2 / 6), 6.08(\mathrm{~d}$, $J=11.0 \mathrm{~Hz}, 2 \mathrm{H}, \mathrm{H}-3 / 5), 5.90\left(\mathrm{~d}, J=6.6 \mathrm{~Hz}, 1 \mathrm{H}, 9^{\prime}-\mathrm{OH}\right), 5.82(\mathrm{~s}, 1 \mathrm{H}, 1-\mathrm{OH}), 4.55\left(\mathrm{~d}, J=6.6 \mathrm{~Hz}, 1 \mathrm{H}, \mathrm{H}-9^{\prime}\right)$, 3.39-3.31 (m, 1H, H-8 $(\mathrm{a})), 3.05-2.96\left(\mathrm{~m}, 1 \mathrm{H}, \mathrm{H}-8_{(\mathrm{b})}\right), 2.63-2.56\left(\mathrm{~m}, 1 \mathrm{H}, \mathrm{H}-3^{\prime}\right), 2.06-1.98\left(\mathrm{~m}, 1 \mathrm{H}, \mathrm{H}-8^{\prime}\right)$, $1.89-1.82\left(\mathrm{~m}, 1 \mathrm{H}, \mathrm{H}-7_{(\mathrm{a})}\right), 1.83-1.77\left(\mathrm{~m}, 1 \mathrm{H}, \mathrm{H}-4^{\prime}{ }_{(\mathrm{a})}\right), 1.80-1.72\left(\mathrm{~m}, 1 \mathrm{H}, \mathrm{H}-7_{(\mathrm{b})}\right), 1.72-1.66\left(\mathrm{~m}, 1 \mathrm{H},{\mathrm{H}-7^{\prime}}_{(\mathrm{a})}\right)$, 1.49-1.35 (m, 3H, H-4 $\left.{ }_{(\mathrm{b})} / 5^{\prime}{ }_{(\mathrm{a})} / 6^{\prime}{ }_{(\mathrm{a})}\right), 1.19-1.06\left(\mathrm{~m}, 1 \mathrm{H}, \mathrm{H}-6^{\prime}{ }_{(\mathrm{b})}\right), 0.95-0.89\left(\mathrm{~m}, 1 \mathrm{H}, \mathrm{H}-5^{\prime}{ }_{(\mathrm{b})}\right), 0.91-0.83$ $\left(\mathrm{m}, 1 \mathrm{H}, \mathrm{H}-7^{\prime}{ }_{(\mathrm{b})}\right)$ ppm; ${ }^{13} \mathrm{C}-\mathrm{NMR}\left(100 \mathrm{MHz}\right.$, DMSO-d $\left.{ }_{6}\right) \delta 185.6(\mathrm{C}-4), 175.2\left(\mathrm{C}-2^{\prime}\right), 153.2(\mathrm{C}-2 / 6), 127.3$ (C-3/5), $85.6\left({\left.\mathrm{C}-9^{\prime}\right)}^{\prime}, 68.1\right.$ (C-1), $40.8\left(\mathrm{C}-8^{\prime}\right), 38.5\left(\mathrm{C}-3^{\prime}\right), 38.1$ (C-7), $35.2(\mathrm{C}-8), 26.3\left(\mathrm{C}-7^{\prime}\right), 23.3\left(\mathrm{C}-6^{\prime}\right), 23.2$ $\left(\mathrm{C}-4^{\prime}\right), 23.1\left(\mathrm{C}-5^{\prime}\right)$ ppm; HRMS (EI) calcd. for $\mathrm{C}_{16} \mathrm{H}_{21} \mathrm{NO}_{4}[\mathrm{M}]^{+}=291.1471$; Found: 291.1469.

\subsection{Cytotoxicity against Human (Cancer) Cells}

\subsubsection{Cell Culture}

Human CCRF-CEM leukemia and MDA-MB-231 breast cancer cells lines were kept in RPMI1640 medium (Gibco ${ }^{\circledR}$, ThermoFisher Scientific Inc., New York, NY, USA), supplemented with $2 \mathrm{mM}$ L-glutamine $\left(\mathrm{Gibco}^{\circledR}\right), 10 \%$ heat-inactivated foetal bovine serum (FBS, Gibco $\left.{ }^{\circledR}\right), 100$ units $/ \mathrm{mL}$ Penicillin (PAA), and $100 \mu \mathrm{g} / \mathrm{mL}$ Streptomycin $\left(\right.$ Gibco $\left.^{\circledR}\right)(1 \%$ Pen/Strep). HCT-116 and U251 cells were cultured in high-glucose Dulbecco's Modified Eagle Medium (DMEM, Gibco ${ }^{\circledR}$ ) containing 2 mM L-glutamine, $10 \%$ FBS, and $1 \%$ Pen/Strep. MRC-5 cells were grown in Minimum Essential Medium (MEM, Gibco ${ }^{\circledR}$ ) supplemented with $2 \mathrm{mM}$ L-glutamine, $10 \%$ FBS, and 1\% Pen/Strep. All cells were kept in a humidified $5 \% \mathrm{CO}_{2}$ atmosphere at $37{ }^{\circ} \mathrm{C}$ and passaged at $90 \%$ confluence.

\subsubsection{XTT Viability Assay}

A Cell Proliferation Kit II (XTT) was purchased from Sigma-Aldrich and performed as described previously [65] and in accordance with the manufacturer's protocol. In brief, adherent cell lines were seeded at a density of 50,000 cells/mL or 100,000 cells/mL (MRC-5) in 96 well plates (100 $\mu \mathrm{L}$, flat bottom) and grown for $24 \mathrm{~h}$ before test compounds were added. Suspension cells (CCRF-CEM) were seeded at 100,000 cells $/ \mathrm{mL}$ and test compounds were added immediately. After $72 \mathrm{~h}$, XTT solution was added for another $90 \mathrm{~min}$ or $4 \mathrm{~h}$ (CCRF-CEM cells) and absorbance was measured at $490 \mathrm{~nm}$ with a reference wave length of $650 \mathrm{~nm}$ (Hidex Sense Microplate Reader 425-301, Hidex, Turku, Finland). Results are expressed as a percentage of the vehicle-treated (0.5\% DMSO) control cells. Vinblastine served as the positive control $(0.01 \mu \mathrm{g} / \mathrm{mL})$. 


\subsection{In Vitro Growth Inhibition Assay of Plasmodium Falciparum NF54}

In vitro activity against erythrocytic stages of $P$. falciparum was determined by a modified $\left[{ }^{3} \mathrm{H}\right]$-hypoxanthine incorporation assay [66] using the drug-sensitive NF54 strain and the standard drug, chloroquine (Sigma C6628). Briefly, parasite cultures incubated in RPMI 1640 medium with $5 \%$ AlbuMAX ${ }^{\mathrm{TM}}$ (without hypoxanthine) were exposed to serial drug dilutions in microtiter plates. After $48 \mathrm{~h}$ of incubation at $37{ }^{\circ} \mathrm{C}$ in a reduced oxygen atmosphere, $0.5 \mu \mathrm{Ci}\left[{ }^{3} \mathrm{H}\right]$-hypoxanthine was added to each well of the plate. Cultures were incubated for a further $24 \mathrm{~h}$ before they were harvested onto glass-fiber filters and washed with distilled water. The radioactivity was counted using a Betaplate $^{\mathrm{TM}}$ liquid scintillation counter (Wallac, Zurich). The results were recorded as counts per minute (CPM) per well at each drug concentration and expressed as a percentage of the untreated controls. $\mathrm{IC}_{50}$ values were calculated from the sigmoidal inhibition curves using Microsoft Excel. Chloroquine was used as the control.

\subsection{In vitro Growth Inhibition Assay of Trypanosoma Brucei Rhodesiense}

Trypanosoma brucei rhodesiense, STIB 900 strain, and the standard drug, melarsoprol, were used for the assay. Minimum Essential Medium (50 $\mu \mathrm{L})$ supplemented with $25 \mathrm{mM}$ HEPES, $1 \mathrm{~g} / \mathrm{L}$ additional glucose, 1\% MEM non-essential amino acids $(100 \times)$, $0.2 \mathrm{mM}$ 2-mercaptoethanol, $1 \mathrm{mM}$ Na-pyruvate, and $15 \%$ heat-inactivated horse serum was added to each well of a 96-well microtiter plate [67]. Serial drug dilutions of 11 three-fold dilution steps covering a range from 100 to $0.002 \mu \mathrm{g} / \mathrm{mL}$ were prepared. Then, $4 \times 10^{3}$ bloodstream forms of T. b. rhodesiense (STIB 900) in $50 \mu \mathrm{L}$ were added to each well and the plate was incubated at $37{ }^{\circ} \mathrm{C}$ under a $5 \% \mathrm{CO}_{2}$ atmosphere for $72 \mathrm{~h} .10 \mu \mathrm{L}$ Alamar Blue (resazurin, $12.5 \mathrm{mg}$ in $100 \mathrm{~mL}$ double-distilled water) was then added to each well and incubation continued for a further 2-4 h [68]. Then, the plates were read with a Spectramax Gemini XS microplate fluorometer (Molecular Devices Cooperation, Sunnyvale, CA, USA) using an excitation wavelength of $536 \mathrm{~nm}$ and an emission wavelength of $588 \mathrm{~nm}$. The $\mathrm{IC}_{50}$ values were calculated from the sigmoidal inhibition curves using the microplate reader software, Softmax Pro (Molecular Devices Cooperation, Sunnyvale, CA, USA). Melarsoprol was used as the control.

\subsection{Cytotoxicity against L6 Cells}

Assays were performed in 96-well microtiter plates, each well containing $100 \mu \mathrm{L}$ of RPMI 1640 medium supplemented with 1\% L-glutamine (200 mM) and 10\% foetal bovine serum, and $4000 \mathrm{~L} 6$ cells (a primary cell line derived from rat skeletal myoblasts). Serial drug dilutions of 11 threefold dilution steps covering a range from 100 to $0.002 \mu \mathrm{g} / \mathrm{mL}$ were prepared. After $72 \mathrm{~h}$ of incubation, the plates were inspected under an inverted microscope to assure growth of the controls and sterile conditions. $10 \mu \mathrm{L}$ of Alamar Blue solution was then added to each well and the plates incubated for another $2 \mathrm{~h}$. Then, the plates were read with a Spectramax Gemini XS microplate fluorometer (Molecular Devices Cooperation, Sunnyvale, CA, USA) using an excitation wavelength of $536 \mathrm{~nm}$ and an emission wavelength of $588 \mathrm{~nm}$. The $\mathrm{IC}_{50}$ values were calculated by linear regression from the sigmoidal dose inhibition curves using the microplate reader software, Softmax Pro (Molecular Devices Cooperation, Sunnyvale, CA, USA). Podophyllotoxin (Sigma P4405) was used as the control.

\section{Conclusions}

In conclusion, we have synthesized a series of jacaranone imides and amines with promising antiproliferative activities from commercially available methyl hydroxyphenyl acetate (4) and tyramine (8). Although the substances showed beneficial physicochemical properties, antiprotozoal effects remained comparatively weak. Imide 13i showed the highest activity against P. falciparum NF54 with an $\mathrm{IC}_{50}$ of $1.28 \mu \mathrm{M}$, while the lowest $\mathrm{IC}_{50}$ against $T$. $b$. rhodesiense was displayed by the morpholine derivate $14 \mathrm{c}$ with $0.27 \mu \mathrm{M}$. The conjugated imides, $13 \mathbf{b}, \mathbf{1 3} \mathbf{e}$, and $\mathbf{1 3} \mathbf{i}$, exhibited the overall highest cytotoxicity against all tested cancer cell lines. 
We are aware that some of the performed chemical modifications did not result in druggable chemical entities. However, we consider that the exploration of a multifaceted chemical lead as present in the jacaranone scaffold through systematic derivatizations may open doors to unexpected biological properties.

Supplementary Materials: Supplementary material associated with this article are available online. Contents: Compared overall yields of the key products. Calculated physicochemical parameters and models. Full results of the XTT viability assay. Data and NMR spectra of the prepared compounds.

Author Contributions: Conceptualization, A.P.; Data curation, A.P., N.K., W.S., R.S., M.K. and M.-M.K.; Formal analysis, A.P. and R.S.; Investigation, G.L., N.K., W.S. and M.-M.K.; Methodology, A.P., G.L., N.K., W.S., R.S., M.K. and M.-M.K.; Project administration, A.P.; Resources, A.P.; Supervision, A.P.; Validation, A.P., N.K., W.S., R.S. and M.K.; Writing—original draft, A.P. and M.-M.K.; Writing—review \& editing, N.K., W.S., R.S. and M.K.

Funding: This research received no external funding.

Acknowledgments: The authors are grateful to Rudolf Bauer for supporting the XTT experiments and Sara Crockett for help in English editing. The authors acknowledge the financial support by the University of Graz.

Conflicts of Interest: The authors declare no conflict of interest.

\section{References}

1. Newman, D.J.; Cragg, G.M. Natural products as sources of new drugs over the 30 years from 1981 to 2010. J. Nat. Prod. 2012, 75, 311-335. [CrossRef] [PubMed]

2. Khazir, J.; Mir, B.A.; Mir, S.A.; Cowan, D. Natural products as lead compounds in drug discovery. J. Asian Nat. Prod. Res. 2013, 15, 764-788. [CrossRef]

3. Brahmachari, G. Natural products in drug discovery: Impacts and opportunities-An assessment. In Bioactive Natural Products; World Scientific Publishing Co Pte Ltd.: Singapore, 2011; pp. 1-199.

4. Harvey, A.L.; Clark, R.L.; Mackay, S.P.; Johnston, B.F. Current strategies for drug discovery through natural products. Expert Opin. Drug Discov. 2010, 5, 559-568. [CrossRef] [PubMed]

5. Kingston, D.G.I. Modern natural products drug discovery and its relevance to biodiversity conservation. J. Nat. Prod. 2011, 74, 496-511. [CrossRef] [PubMed]

6. Mishra, B.B.; Tiwari, V.K. Natural products: An evolving role in future drug discovery. Eur. J. Med. Chem. 2011, 46, 4769-4807. [CrossRef] [PubMed]

7. Montaser, R.; Luesch, H. Marine natural products: A new wave of drugs? Future Med. Chem. 2011, 3, 1475-1489. [CrossRef] [PubMed]

8. Koehn, F.E. Biosynthetic medicinal chemistry of natural product drugs. MedChemComm 2012, 3, 854-865. [CrossRef]

9. Cragg, G.M.; Newman, D.J. Natural products: A continuing source of novel drug leads. Biochim. Biophys. Acta Gen. Subj. 2013, 1830, 3670-3695. [CrossRef] [PubMed]

10. Choi, H.; Oh, D.-C. Considerations of the chemical biology of microbial natural products provide an effective drug discovery strategy. Arch. Pharm. Res. 2015, 38, 1591-1605. [CrossRef] [PubMed]

11. Gachet, M.S.; Kunert, O.; Kaiser, M.; Brun, R.; Munoz, R.A.; Bauer, R.; Schuhly, W. Jacaranone-derived glucosidic esters from Jacaranda glabra and their activity against Plasmodium falciparum. J. Nat. Prod. 2010, 73, 553-556. [CrossRef] [PubMed]

12. Lozada-Lechuga, J.; Villarreal, M.L.; Fliniaux, M.-A.; Bensaddek, L.; Mesnard, F.; del Carmen Gutiérrez, M.; Cardoso-Taketa, A.T. Isolation of jacaranone, a sedative constituent extracted from the flowers of the Mexican tree Ternstroemia pringlei. J. Ethnopharmacol. 2010, 127, 551-554. [CrossRef] [PubMed]

13. Massaoka, M.H.; Matsuo, A.L.; Figueiredo, C.R.; Farias, C.F.; Girola, N.; Arruda, D.C.; Scutti, J.A.B.; Romoff, P.; Favero, O.A.; Ferreira, M.J.P.; et al. Jacaranone induces apoptosis in melanoma cells via ROS-mediated downregulation of Akt and p38 MAPK activation and displays antitumor activity in vivo. PLoS ONE 2012, 7, e38698. [CrossRef] [PubMed]

14. Morais, T.R.; Romoff, P.; Favero, O.A.; Reimao, J.Q.; Lourenco, W.C.; Tempone, A.G.; Hristov, A.D.; Di Santi, S.M.; Lago, J.H.G.; Sartorelli, P.; et al. Anti-malarial, anti-trypanosomal, and anti-leishmanial activities of jacaranone isolated from Pentacalia desiderabilis (Vell.) Cuatrec. (Asteraceae). Parasitol. Res. 2012, 110, 95-101. [CrossRef] [PubMed] 
15. Akendengue, B.; Ngou-Milama, E.; Roblot, F.; Laurens, A.; Hocquemiller, R.; Grellier, P.; Frappier, F. Antiplasmodial activity of Uvaria klaineana. Planta Med. 2002, 68, 167-169. [CrossRef] [PubMed]

16. Adams, M.; Wube, A.A.; Bucar, F.; Bauer, R.; Kunert, O.; Haslinger, E. Quinolone alkaloids from Evodia rutaecarpa: A potent new group of antimycobacterial compounds. Int. J. Antimicrob. Agents 2005, 26, 262-264. [CrossRef] [PubMed]

17. Dijoux, M.-G.; Schnabel, P.C.; Hallock, Y.F.; Boswell, J.L.; Johnson, T.R.; Wilson, J.A.; Ireland, C.M.; van Soest, R.; Boyd, M.R.; Barrows, L.R.; et al. Antitumor activity and distribution of pyrroloiminoquinones in the sponge genus Zyzzya. Bioorg. Med. Chem. 2005, 13, 6035-6044. [CrossRef] [PubMed]

18. Jeon, J.-E.; Na, Z.; Jung, M.; Lee, H.-S.; Sim, C.J.; Nahm, K.; Oh, K.-B.; Shin, J. Discorhabdins from the Korean marine sponge Sceptrella sp. J. Nat. Prod. 2010, 73, 258-262. [CrossRef] [PubMed]

19. Sallam, A.A.; Ramasahayam, S.; Meyer, S.A.; El Sayed, K.A. Design, synthesis, and biological evaluation of dibromotyrosine analogues inspired by marine natural products as inhibitors of human prostate cancer proliferation, invasion, and migration. Bioorg. Med. Chem. 2010, 18, 7446-7457. [CrossRef] [PubMed]

20. Chan, H.-H.; Hwang, T.-L.; Thang, T.D.; Leu, Y.-L.; Kuo, P.-C.; Nguyet, B.T.M.; Dai, D.N.; Wu, T.-S. Isolation and synthesis of melodamide $\mathrm{A}$, a new anti-inflammatory phenolic amide from the leaves of Melodorum fruticosum. Planta Med. 2013, 79, 288-294. [CrossRef] [PubMed]

21. Abdel-Aziz, A.A.-M. Novel and versatile methodology for synthesis of cyclic imides and evaluation of their cytotoxic, DNA binding, apoptotic inducing activities and molecular modeling study. Eur. J. Med. Chem. 2007, 42, 614-626. [CrossRef] [PubMed]

22. Mitsunobu, $\mathrm{O}$. The use of diethyl azodicarboxylate and triphenylphosphine in synthesis and transformation of natural products. Synthesis 1981,1-28. [CrossRef]

23. Wetter, H.; Oertle, K. Thexyldimethylsilyl chloride, an easily accessible reagent for the protection of alcohols. Tetrahedron Lett. 1985, 26, 5515-5518. [CrossRef]

24. Corey, E.J.; Venkateswarlu, A. Protection of hydroxyl groups as tert-butyldimethylsilyl derivatives. J. Am. Chem. Soc. 1972, 94, 6190-6191. [CrossRef]

25. Walker, M.A. A High Yielding Synthesis of N-Alkyl Maleimides using a novel modification of the mitsunobu reaction. J. Org. Chem. 1995, 60, 5352-5355. [CrossRef]

26. Lima, L.M.; Barreiro, E.J.; Fraga, C.A.M. O-alkylation of bioactive phthalimide derivatives under microwave irradiation in dry media. Synth. Commun. 2000, 30, 3291-3306. [CrossRef]

27. Chen, J.; Spear, S.K.; Huddleston, J.G.; Rogers, R.D. Polyethylene glycol and solutions of polyethylene glycol as green reaction media. Green Chem. 2005, 7, 64-82. [CrossRef]

28. Liang, J.; Lv, J.; Fan, J.-C.; Shang, Z.-C. Polyethylene Glycol as a Nonionic Liquid Solvent for the Synthesis of N-Alkyl and N-Arylimides. Synth. Commun. 2009, 39, 2822-2828. [CrossRef]

29. Jain, S.L.; Singhal, S.; Sain, B. PEG-assisted solvent and catalyst free synthesis of 3,4-dihydropyrimidinones under mild reaction conditions. Green Chem. 2007, 9, 740-741. [CrossRef]

30. Bähn, S.; Imm, S.; Neubert, L.; Zhang, M.; Neumann, H.; Beller, M. The Catalytic Amination of Alcohols. ChemCatChem 2011, 3, 1853-1864. [CrossRef]

31. Smith, M.B.; March, J. March's Advanced Organic Chemistry: Reactions, Mechanisms, and Structure, 7 rev. ed.; Wiley: Hoboken, NJ, USA, 2012.

32. Watson, T.J.; Ayers, T.A.; Shah, N.; Wenstrup, D.; Webster, M.; Freund, D.; Horgan, S.; Carey, J.P. Process improvements for the preparation of kilo quantities of a series of isoindoline compounds. Org. Process Res. Dev. 2003, 7, 521-532. [CrossRef]

33. Artamonov, O.S.; Slobodyanyuk, E.Y.; Shishkin, O.V.; Komarov, I.V.; Mykhailiuk, P.K. Synthesis of isomeric 6-trifluoromethyl-3-azabicyclo[3.1.0]hexanes: Conformationally restricted analogues of 4-trifluoromethylpiperidine. Synthesis 2013, 45, 225-230. [CrossRef]

34. Pan, S.; Shibata, T. Recent advances in iridium-catalyzed alkylation of C-H and N-H bonds. ACS Catal. 2013, 3, 704-712. [CrossRef]

35. Fujita, K.-I.; Enoki, Y.; Yamaguchi, R. Cp*Ir-catalyzed N-alkylation of amines with alcohols. A versatile and atom economical method for the synthesis of amines. Tetrahedron 2008, 64, 1943-1954. [CrossRef]

36. Iranpoor, N.; Firouzabadi, H.; Aghapour, G.; Vaez zadeh, A.R. Triphenylphosphine/2,3-dichloro5,6-dicyanobenzoquinone as a new, selective and neutral system for the facile conversion of alcohols, thiols and selenols to alkyl halides in the presence of halide ions. Tetrahedron 2002, 58, 8689-8693. [CrossRef] 
37. Li, D.; Chen, S.; Bellomo, E.A.; Tarasov, A.I.; Kaut, C.; Rutter, G.A.; Li, W.-H. Imaging dynamic insulin release using a fluorescent zinc indicator for monitoring induced exocytotic release (ZIMIR). Proc. Natl. Acad. Sci. USA 2011, 108, 21063-21068. [CrossRef] [PubMed]

38. Ankala, S.V.; Fenteany, G. Selective deprotection of either alkyl or aryl silyl ethers from aryl, alkyl bis-silyl ethers. Tetrahedron Lett. 2002, 43, 4729-4732. [CrossRef]

39. Hou, D.-R.; Hsieh, Y.-D.; Hsieh, Y.-W. New formation of 4,5,6,7-tetrahydroisoindoles. Tetrahedron Lett. 2005, 46, 5927-5929. [CrossRef]

40. Hou, D.-R.; Wang, M.-S.; Chung, M.-W.; Hsieh, Y.-D.; Tsai, H.-H.G. Formation of 4,5,6,7-Tetrahydroisoindoles by Palladium-Catalyzed Hydride Reduction. J. Org. Chem. 2007, 72, 9231-9239. [CrossRef] [PubMed]

41. Felpin, F.-X. Oxidation of 4-arylphenol trimethylsilyl ethers to $p$-arylquinols using hypervalent iodine(III) reagents. Tetrahedron Lett. 2007, 48, 409-412. [CrossRef]

42. Magdziak, D.; Meek, S.J.; Pettus, T.R.R. Cyclohexadienone ketals and quinols: Four building blocks potentially useful for enantioselective synthesis. Chem. Rev. 2004, 104, 1383-1430. [CrossRef] [PubMed]

43. Quideau, S.; Pouysegu, L.; Deffieux, D. Oxidative dearomatization of phenols. Why, how and what for? Synlett 2008, 467-495. [CrossRef]

44. Roche, S.P.; Porco, J.A., Jr. Dearomatization strategies in the synthesis of complex natural products. Angew. Chem. Int. Ed. 2011, 50, 4068-4093. [CrossRef] [PubMed]

45. Harned, A.M. Asymmetric oxidative dearomatizations promoted by hypervalent iodine(III) reagents: An opportunity for rational catalyst design? Tetrahedron Lett. 2014, 55, 4681-4689. [CrossRef] [PubMed]

46. You, Z.; Hoveyda, A.H.; Snapper, M.L. Catalytic enantioselective silylation of acyclic and cyclic triols: Application to total syntheses of cleroindicins D, F, and C. Angew. Chem. Int. Ed. 2009, 48, 547-550. [CrossRef] [PubMed]

47. Gleeson, M.P.; Hersey, A.; Montanari, D.; Overington, J. Probing the links between in vitro potency, ADMET and physicochemical parameters. Nat. Rev. Drug Discov. 2011, 10, 197-208. [CrossRef] [PubMed]

48. Leeson, P.D.; Oprea, T.I. Drug-like physicochemical properties. In Drug Design Strategies: Quantitative Approaches; Livingstone, D.J., Davis, A.M., Eds.; Royal Society of Chemistry: Cambridge, UK, 2012; pp. 35-59.

49. Tian, S.; Wang, J.; Li, Y.; Li, D.; Xu, L.; Hou, T. The application of in silico drug-likeness predictions in pharmaceutical research. Adv. Drug Delivery Rev. 2015, 86, 2-10. [CrossRef] [PubMed]

50. Pajouhesh, H.; Lenz, G.R. Medicinal chemical properties of successful central nervous system drugs. NeuroRx 2005, 2, 541-553. [CrossRef] [PubMed]

51. Bytheway, I.; Darley, M.G.; Popelier, P.L.A. The calculation of polar surface area from first principles: An application of quantum chemical topology to drug design. ChemMedChem 2008, 3, 445-453. [CrossRef] [PubMed]

52. Ferrins, L.; Gazdik, M.; Rahmani, R.; Varghese, S.; Sykes, M.L.; Jones, A.J.; Avery, V.M.; White, K.L.; Ryan, E.; Charman, S.A.; et al. Pyridyl benzamides as a novel class of potent inhibitors for the kinetoplastid Trypanosoma brucei. J. Med. Chem. 2014, 57, 6393-6402. [CrossRef] [PubMed]

53. Lipinski, C.A.; Lombardo, F.; Dominy, B.W.; Feeney, P.J. Experimental and computational approaches to estimate solubility and permeability in drug discovery and development settings. Adv. Drug Delivery Rev. 2012, 64, 4-17. [CrossRef]

54. Veber, D.F.; Johnson, S.R.; Cheng, H.-Y.; Smith, B.R.; Ward, K.W.; Kopple, K.D. molecular properties that influence the oral bioavailability of drug candidates. J. Med. Chem. 2002, 45, 2615-2623. [CrossRef] [PubMed]

55. Ghose, A.K.; Viswanadhan, V.N.; Wendoloski, J.J. A Knowledge-based approach in designing combinatorial or medicinal chemistry libraries for drug discovery. 1. A qualitative and quantitative characterization of known drug databases. J. Comb. Chem. 1999, 1, 55-68. [CrossRef] [PubMed]

56. Hopkins, A.L.; Keserü, G.M.; Leeson, P.D.; Rees, D.C.; Reynolds, C.H. The role of ligand efficiency metrics in drug discovery. Nat. Rev. Drug Discov. 2014, 13, 105-121. [CrossRef] [PubMed]

57. Cavalluzzi, M.M.; Mangiatordi, G.F.; Nicolotti, O.; Lentini, G. Ligand efficiency metrics in drug discovery: The pros and cons from a practical perspective. Expert Opin. Drug Discov. 2017, 12, 1087-1104. [CrossRef] [PubMed]

58. Daina, A.; Zoete, V. A BOILED-Egg to Predict Gastrointestinal Absorption and Brain Penetration of Small Molecules. ChemMedChem 2016, 11, 1117-1121. [CrossRef] [PubMed]

59. Daina, A.; Michielin, O.; Zoete, V. SwissADME: A free web tool to evaluate pharmacokinetics, drug-likeness and medicinal chemistry friendliness of small molecules. Sci. Rep. 2017, 7, 42717. [CrossRef] [PubMed] 
60. Egan, W.J.; Merz, K.M., Jr.; Baldwin, J.J. Prediction of drug absorption using multivariate statistics. J. Med. Chem. 2000, 43, 3867-3877. [CrossRef] [PubMed]

61. Nwaka, S.; Ramirez, B.; Brun, R.; Maes, L.; Douglas, F.; Ridley, R. Advancing drug innovation for neglected diseases-criteria for lead progression. PLoS Negl. Trop. Dis. 2009, 3, 1-13. [CrossRef] [PubMed]

62. Klotz, L.-O.; Hou, X.; Jacob, C. 1,4-naphthoquinones: From oxidative damage to cellular and inter-cellular signaling. Molecules 2014, 19, 14902-14918. [CrossRef] [PubMed]

63. Circu, M.L.; Aw, T.Y. Reactive oxygen species, cellular redox systems, and apoptosis. Free Radic. Biol. Med. 2010, 48, 749-762. [CrossRef] [PubMed]

64. Carneiro, P.F.; Pinto, M.C.R.F.; Marra, R.K.F.; da Silva, F.d.C.; Resende, J.A.L.C.; e Silva, L.F.R.; Alves, H.G.; Barbosa, G.S.; de Vasconcellos, M.C.; Lima, E.S.; et al. Synthesis and antimalarial activity of quinones and structurally-related oxirane derivatives. Eur. J. Med. Chem. 2016, 108, 134-140. [CrossRef] [PubMed]

65. Rinner, B.; Kretschmer, N.; Knausz, H.; Mayer, A.; Boechzelt, H.; Hao, X.-J.; Heubl, G.; Efferth, T.; Schaider, H.; Bauer, R. A petrol ether extract of the roots of Onosma paniculatum induces cell death in a caspase dependent manner. J. Ethnopharmacol. 2010, 129, 182-188. [CrossRef] [PubMed]

66. Matile, H.; Richard, J.; Pink, L. Plasmodium falciparum malaria parasite cultures and their use in immunology. In Immunological Methods, Volume IV; Lefkovits, I., Pernis, B., Eds.; Academic Press: Cambridge, MA, USA, 1990; pp. 221-234.

67. Baltz, T.; Baltz, D.; Giroud, C.; Crockett, J. Cultivation in a semi-defined medium of animal infective forms of Trypanosoma brucei, T. equiperdum, T. evansi, T. rhodesiense and T. gambiense. EMBO J. 1985, 4, 1273-1277. [CrossRef] [PubMed]

68. Räz, B.; Iten, M.; Grether-Bühler, Y.; Kaminsky, R.; Brun, R. The Alamar Blue assay to determine drug sensitivity of African trypanosomes (T.b. rhodesiense and T.b. gambiense) in vitro. Acta Trop. 1997, 68, 139-147. [CrossRef]

Sample Availability: Samples of the compounds 13a-j, 14a, 14c and 15 are available from the authors.

(C) 2018 by the authors. Licensee MDPI, Basel, Switzerland. This article is an open access article distributed under the terms and conditions of the Creative Commons Attribution (CC BY) license (http://creativecommons.org/licenses/by/4.0/). 